\title{
Effect of resident microbiota on the solubilization of gold in soil from the Tomakin Park Gold Mine, New South Wales, Australia
}

\author{
F. Reith ${ }^{\mathrm{a}, \mathrm{b}, \mathrm{c}, *}$, D.C. McPhail ${ }^{\mathrm{a}, \mathrm{b}}$ \\ ${ }^{a}$ Cooperative Research Centre for Landscape Environments and Mineral Exploration, Building 47, \\ The Australian National University, Canberra ACT 0200, Australia \\ ${ }^{\mathrm{b}}$ Department of Earth and Marine Sciences, Building 47, The Australian National University, Canberra ACT 0200, Australia \\ ${ }^{c}$ School of Biochemistry and Molecular Biology, Building 41, The Australian National University, Canberra ACT 0200, Australia
}

Received 15 March 2005; accepted in revised form 14 November 2005

\begin{abstract}
The processes influencing the solubilization and observed mobility of Au in soil were studied using a combination of geochemical and microbiological techniques. In this study, we demonstrate for the first time that biotic processes mediated by the resident microbiota are likely to control the mobilization of $\mathrm{Au}$ in auriferous soils and other regolith materials. Microcosms with auriferous soils from the Tomakin Park Gold Mine in temperate south eastern New South Wales, Australia, were incubated under biologically active versus inactive (sterilized) conditions. The soils were incubated oxic and anoxic, unamended and Au pellet- or cycloheximide amended for 70 days in a 1:4 (w:v) aqueous slurry at $25^{\circ} \mathrm{C}$ in the dark. In biologically active unamended Ah- and B-horizon microcosms up to $80 \mathrm{wt} . \%$ of total Au was detected in solution after 45 days of incubation. In biologically active Au pellet amended microcosms Au was liberated from the soil and also from added Au pellets. Scanning electron microscopy and nucleic acid staining combined with confocal stereo laser microscopy revealed the presence of bacterial biofilms on Au pellets incubated in the biologically active microcosms. The biologically inactive microcosms displayed no or significantly reduced Au solubilization. After 40-50 days of incubation Au was generally re-adsorbed to the solid soil fractions. The results of sequential extractions conducted with dried slurry samples collected from the biologically active Ah-horizon microcosms after $0,10,20,30,40$, and 68 days of incubation indicated a continuous microscale solubilization and re-adsorption of Au. In samples taken after 40 days of incubation more than $80 \mathrm{wt} . \%$ of the Au was extracted from the operationally defined organic fraction, which appears to act as a final re-adsorption site for Au in the soil. In samples taken after 10 days of incubation from microcosms amended with $100 \mu \mathrm{g} \mathrm{g}^{-1}$ (d.w. soil) of $\mathrm{Au}$ as $\mathrm{AuCl}_{4}{ }^{-} 95 \mathrm{wt} . \%$ of the $\mathrm{Au}$ was associated with the organic fraction. To establish a mechanistic link between $\mathrm{Au}$ dissolution and re-adsorption with the activity of the heterotrophic bacterial community, analysis of the community structure based on carbon utilization patterns using was conducted. The bacterial community structure changed from a carbohydrate- and polymer-utilizing to a carboxylic- and amino acid utilizing community concurrently with the change from Au solubilization to re-adsorption. The bacterial community in the early stages of incubation (0-30 days) apparently produced an excess of amino acids, which are known to form stable amino acid Au complexes. The bacterial community in the later stages of incubation (after 40-50 days) metabolized these Au complexing ligands and $\mathrm{Au}$, which apparently became unstable in the solution, was re-adsorbed to the solid soil fractions. (c) 2005 Elsevier Inc. All rights reserved.
\end{abstract}

\section{Introduction}

The formation of lateritic Au deposits and anomalies in the regolith depends on the mobilization, transport, and

\footnotetext{
${ }^{*}$ Corresponding author. Present address: CSIRO Land and Water, PMB 2, Glen Osmond, 5064, South Australia, Australia. Fax: +61 88303 8560.

E-mail address: frank.reith@anu.edu.au (F. Reith).
}

precipitation of $\mathrm{Au}$ in the weathering environment (e.g., Wilson, 1984), and recent studies using sequential extractions have shown that $\mathrm{Au}$ is mobile in soils and deeper regolith materials in and around mineralized zones (e.g., Mann, 1984; Grimm and Friedrich, 1988; Gray and Lintern, 1998; Reith et al., 2005). For instance, at the Tomakin Park Gold Mine approximately $50 \mathrm{wt} \%$ of the total $\mathrm{Au}$ in the Ah-horizon overlying the mineralized zone was associated with the following operationally defined fractions: 
water-, ammonium acetate-, sodium pyrophosphate-, and hydroxylamine hydrochloride-soluble fractions. In contrast, in the unweathered quartz-vein material more than $95 \mathrm{wt} . \%$ of the Au was only extractable with concentrated aqua regia and appeared to be strongly bound in pyrite and arsenopyrite (Reith et al., 2005).

The processes involved in the mobilization of $\mathrm{Au}$ in the regolith are believed to be abiotic. For instance, Gray (1998) postulated the following mechanisms in an attempt to explain the observed solubilization of $\mathrm{Au}$ : (i) oxidation and dissolution of $\mathrm{Au}$ due to higher concentration of dissolved $\mathrm{O}_{2}$ in the supergene environment; (ii) release of $\mathrm{Au}$ during abiotic mineral weathering; (iii) mechanical abrasion of native Au due to swelling of minerals during alteration; and; (iv) increased concentration of ligand molecules such as chloride, sulfide, or thiosulfate. However, $\mathrm{Au}$ is widely present in the biosphere indicating that biogeochemical cycling and processes are important (e.g., Korobushkina et al., 1983).

There is growing evidence that suggests that biota are important in affecting the cycling of Au. Plants, algae, actinomycetes, and fungi have been found to accumulate $\mathrm{Au}$ (e.g., Korobushkina et al., 1983; Hosea et al., 1986; Mossman et al., 1999; Nakajima, 2003). Studies have also shown that common bacteria such as Bacillus subtilis or Escherichia coli are capable of precipitating Au from solution and accumulating it extra- and intracellularly (Beveridge and Murray, 1976; Karamushka et al., 1987a,b; Ulberg et al., 1992; Southam and Beveridge, 1996; Savvaidis et al., 1998; Karthikeyan and Beveridge, 2002; Nakajima, 2003). Morphological evidence for microbially mediated authigenic formation of secondary Au nuggets in regolith- and placer deposits has also been reported (Bischoff, 1994, 1997; Bischoff et al., 1992; Keeling, 1993; Mann, 1992). In addition, $\mathrm{Au}$ has been shown to play a functional role in the membrane-bound enzyme NADH-oxidase used by Micrococcus luteus during the oxidation of methane (Levchenko et al., 2002).

Microbiologists have conducted in vitro experiments with a variety of common soil bacteria that have shown their capacity to mobilize Au. Pares and Martinet (1964) found that $\mathrm{Au}$ from laterites and various other $\mathrm{Au}$-bearing materials can be solubilized by unidentified autotrophic $\mathrm{N}_{2}$-fixing bacteria and various heterotrophic bacteria such as Serratia marcescens and Pseudomonas fluorescens. Lyalikova and Mockeicheva (1969) found that a number of heterotrophic bacteria are able to dissolve Au. A strain similar to Bacillus alvei isolated from a $\mathrm{Au}$ deposit dissolved up to $600 \mu \mathrm{g} \mathrm{L}^{-1}$ of Au in a microbial growth medium within 3 weeks (Boyle, 1979). Strains of Bacillus megaterium, Bacillus mesentericus, Pseudomonas liquefaciens, and Bacterium nitrificans were found to dissolve up to $35 \mathrm{mg} \mathrm{L}^{-1}$ of $\mathrm{Au}$ during 30 days of incubation (Korobushkina et al., 1974). Iron- and sulfur-oxidizing bacteria such as strains of Acidithiobacillus sp. and Leptospirillum $s p$. have been observed to mediate the release Au by breaking down the sulfides in sulfidic Au ore (e.g., Iglesias and
Carranza, 1995; Sandstroem and Peterson, 1997; Ubaldini et al., 2000), and some of these strains are used in industrial bioleaching processes to extract metals from ore (e.g., Bosecker, 1997).

Understanding the role of microorganisms in the regolith is complicated because regolith materials consist of complex inorganic and organic matrices with distinct abiotic and biotic phases. We need to know if the microbiota present in the regolith can mobilize $\mathrm{Au}$, and thus facilitate its transport, and also if they play a role in precipitation and adsorption processes that counteract the mobilization of Au. Gold complexes in solution are readily adsorbed by solid inorganic and organic phases. For instance, $\mathrm{Au}(\mathrm{I} /$ III)-complexes have been shown to readily adsorb onto clays, carbonates, Fe-oxides and -oxyhydroxides such as hematite and goethite and organics such as humic and fulvic acids as well as microbiota (e.g., Linter and Butt, 1993; Greffie et al., 1996; Ran et al., 2002; Nakajima, 2003).

Microcosm experiments under well-controlled biogeochemical conditions provide an opportunity to demonstrate that microbiota resident in auriferous soils and deeper regolith materials play a role in the solubilization of Au, but to the authors' knowledge no microcosm studies have been conducted. Therefore, the aims of this study are to: (i) evaluate if the resident microbiota of auriferous soil can mobilize $\mathrm{Au}$; (ii) assess the microbially mediated solubilization and re-adsorption of $\mathrm{Au}$ in natural samples by developing suitable microcosm experiments; (iii) explore the association of $\mathrm{Au}$ with the different solid soil fractions known to adsorb trace elements, and; (iv) link the functional structure of bacterial community with the process of $\mathrm{Au}$ solubilization.

These aims were accomplished by using microcosm experiments, in which the changes in solution composition, microbial activity and populations, and the association of $\mathrm{Au}$ with the solid phases of the soil were monitored. Soil samples from the Tomakin Park Gold Mine in south eastern Australia were used for this study, because the regolith profile on top of the underground mine is undisturbed, the regolith is well characterized, and a previous study has indicated that $\mathrm{Au}$ is mobilized during weathering (Reith et al., 2005).

\section{Study area description}

The Tomakin Park Gold Mine is located $2 \mathrm{~km}$ west of the coastal village of Tomakin in south eastern New South Wales, Australia, at S $35^{\circ} 48^{\prime} 51.9^{\prime \prime}$ and E $150^{\circ} 10^{\prime} 26.4^{\prime \prime}$ (Fig. 1). A detailed description of the geology, the regolith-, and soil properties and the mineralogy is given in Reith et al. (2005), so we only provide a brief summary here. The mine is located in the Molong-South Coast Anticlinorial Zone, which is a structural subdivision of the Lachlan Fold Belt. The regional geology consists of an anticlinorial zone, which displays a large, north-south elongated, cratonised block of Ordovician flysch sediments overlain by Middle to Late Devonian rift volcanics and 


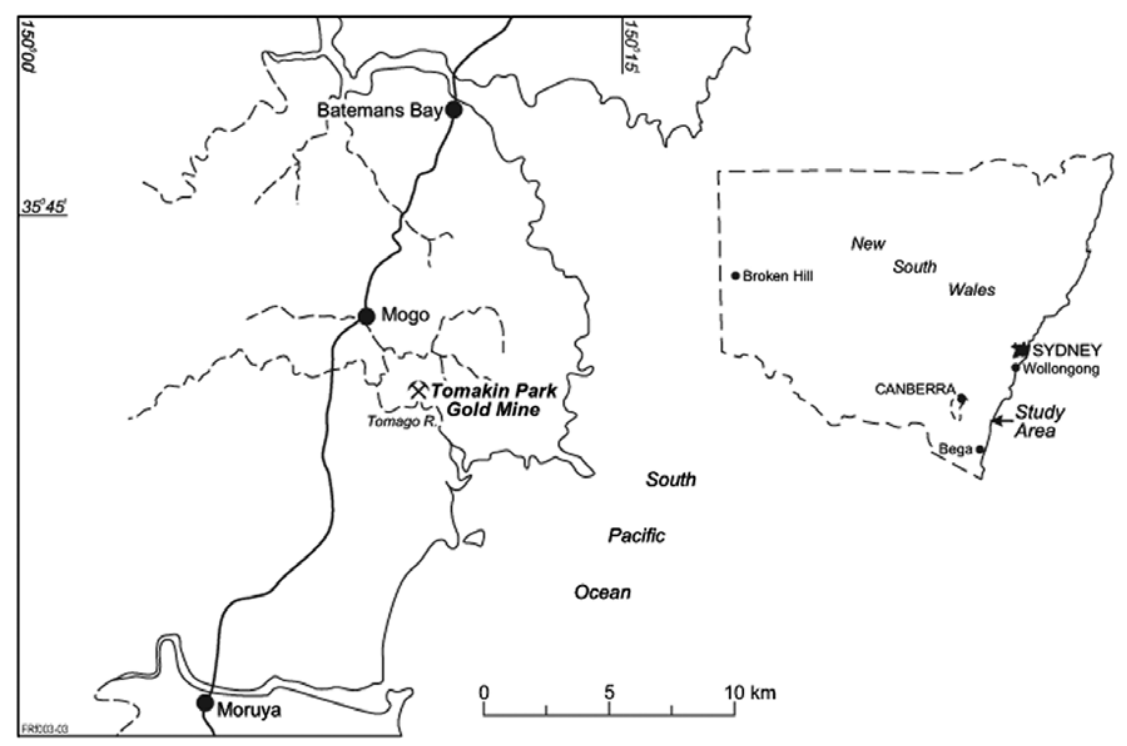

Fig. 1. Location map of the Tomakin Park Gold Mine in south eastern New South Wales, Australia.

Late Devonian transitional and cratonic sediments. The primary ore consists of massive and disseminated arsenopyrite and pyrite that contain $\mathrm{Au}$ in solid solution or as small inclusions (Bowman, 1979).

The climate in the region is temperate and controlled by its proximity to the Pacific Ocean (Fig. 1). Average annual temperatures and rainfall approximate are $15^{\circ} \mathrm{C}$ and $1000 \mathrm{~mm}$, respectively. The study area lies between 10 and $60 \mathrm{~m}$ above sea level and the landscape is characterized by narrow ridgelines with gentle to very steep side slopes. The regolith cover is moderately to intensely weathered to depths of up to several meters. The vegetation covering the area is predominantly Sclerophyll forest, as described in Reith et al. (2005).

Field analyses of soils, after McDonald et al. (1998), show that the soils are colluvial cambisols. A typical soil profile (thickness) consists of 1-3 cm O-horizon, $3-12 \mathrm{~cm}$ Ah-horizon, 15-20 cm B 1 -horizon, and 50-100 $\mathrm{cm} \mathrm{B}_{2}$-horizon, which overlie a moderately weathered saprock C-horizon. The soil textures are predominantly sandy or silty clay loams with gravel contents of up to $30 \mathrm{vol} \%$. A few, i.e., $<2 \%$, orange to pale brown mottles were detected in the B-horizon. The mineralogy, grain size total $\mathrm{C}$ and $\mathrm{N}$ and $\mathrm{pH}$ of the soils and deeper regolith materials used in our experiments are given in Table 1.

\section{Materials and methods}

\subsection{Sampling procedures and locations}

Soil and vein-quartz materials were collected in June 2002, July 2003, and October 2003 for microcosms, sequential extractions, and community structure analyses using a flame-sterilized hammer, hand shovel, and sieve. Soil samples from the Ah- and B-horizons were collected from 3 to $5 \mathrm{~cm}$ and 15 to $20 \mathrm{~cm}$ depths, respectively, from soil direct-
Table 1

Mineralogy and properties of the auriferous soil and vein-quartz samples used in the microcosms

\begin{tabular}{lccc}
\hline & Ah-horizon & B-horizon & $\begin{array}{l}\text { Quartz-vein } \\
\text { material }\end{array}$ \\
\hline Mineralogy ${ }^{\mathrm{a}}$ (\%) & & & \\
Quartz & 80.1 & 47.3 & 96.4 \\
Albite & 1.3 & 1.2 & 1.4 \\
Muscovite & 12.2 & 42.5 & 0.7 \\
Kaolin & 1.0 & 5.1 & 0.1 \\
Illite & 0.2 & 0.2 & 0.2 \\
Goethite & 0.4 & 1.3 & 0.6 \\
Microcline & 2.1 & n.d. & n.d. \\
Halloysite & 0.2 & n.d. & n.d. \\
Pyrophillite & n.d. & n.d. & 0.4 \\
Biotite & n.d. & 1.4 & n.d. \\
Rutile & n.d. & 1.0 & n.d. \\
Size fraction analysis (\%) & & & \\
Coarse sand & 23 & 24 & n.a. \\
Fine sand & 30 & 20 & n.a. \\
Silt & 25 & 25 & n.a. \\
Clay & 11 & 32 & n.a. \\
Total C [wt.\%] & 9.6 & 0.7 & n.d. \\
Total N [wt.\%] & 0.33 & 0.09 & n.d. \\
pH (1:5 extract in water) & 5.5 & 6.0 & 5.2 \\
\hline
\end{tabular}

${ }^{a}$ Mineralogy was summarized from Reith et al. (2005) and was measured using XRD combined with the SIROQUANT software.

${ }^{b}$ n.d., not detected.

${ }^{c}$ n.a., not applicable.

ly overlying the primary $\mathrm{Au}$ deposit (notated in tables and figures as $\mathrm{A}$ and $\mathrm{B}$ ) and from a site located $100 \mathrm{~m}$ away from the outcropping vein (notated as A100, B100). Soil samples from $100 \mathrm{~m}$ distance represent background $\mathrm{Au}$ concentrations in the soil, based on our previous study (Reith et al., 2005). Soil samples were sieved on site to $<2 \mathrm{~mm}$ size, stored in sterile plastic bags and transported over ice to the laboratory. Material was collected from the quartz-vein within the underground workings and hammered to rock chips on site using the method described 
by (Hirsch et al., 1995). In the laboratory, the quartz chips were ground in a flame-sterilized tungsten-carbide ring mill and sieved to $<200 \mu \mathrm{m}$ size under sterile conditions.

\subsection{Microcosm experiments}

Batch-type microcosms with soils and vein-quartz materials were incubated as aqueous slurries on a rotary shaker at $25^{\circ} \mathrm{C}$ for up to 70 days. Seventy-five grams (dry weight) of solid material (biologically active or inactive - see below) plus $300 \mathrm{ml}$ double deionized sterile water (1:4 (w:v); chosen to allow up to ten $5 \mathrm{ml}$ water samples per experiment) were placed under sterile conditions into $500 \mathrm{ml}$ infusion bottles (Ochs, Bovenden-Lenglern, Germany). Experiments were conducted under oxic or anoxic conditions without amendment, or amended with Au pellets, $100 \mu \mathrm{gg}^{-1}$ (d.w. soil) of dissolved $\mathrm{Au}\left(\mathrm{AuCl}_{4}{ }^{-}\right)$or cycloheximide. Specific conditions for all experiments are listed in Table 2. Microcosms were named according to a code based on the experimental conditions, for instance, $\mathrm{AJ} 2-\mathrm{a}+\mathrm{Au}$ stands for a microcosm with Ah-horizon material collected in June 2002 that was incubated biologically active and amended with 2 Au pellets. Oxic microcosms were plugged with sterile cotton wool to allow $\mathrm{O}_{2}$ exchange with the atmosphere and incubated on a shaking incubator at $25^{\circ} \mathrm{C}$ and $100 \mathrm{rpm}$ (rounds per minute) in the dark. Dissolved oxygen (DO) levels in the water were checked in microcosms AJ2-a and BJ2-a using a 1469-00 OX-2P dissolved- $\mathrm{O}_{2}$ Kit (Hach, Belgium) at days 10 and 68 and ranged between 4.7 and $6.3 \mathrm{mg} \mathrm{L}^{-1}$, compared with $\mathrm{DO}=7.9 \mathrm{mg} \mathrm{L}^{-1}$ in water saturated with atmospheric $\mathrm{O}_{2}$ at $25^{\circ} \mathrm{C}$. Other experiments under oxic conditions were assumed to contain similar concentrations of oxygen. Anoxic conditions in microcosms AJ2-a $+\mathrm{Au}-\mathrm{an}$ and $\mathrm{BJ} 2-\mathrm{a}+\mathrm{Au}-$ an were established by flushing the infusion bottles with sterile Ar for $20 \mathrm{~min}$ after the solid samples were introduced, closing the bottles with rubber stoppers and screw-cap seals and then adding anoxic water from sterile syringes through the rubber stoppers. Gas chromatography was used to check remaining $\mathrm{O}_{2(\mathrm{~g})}$ levels in the bottles and none was detected. Anoxic microcosms were incubated static at $25^{\circ} \mathrm{C}$ in the dark. Some microcosms were amended with sterilized 99.999\% pure Au pellets (0.1-0.2 mm in diameter; Johnson Matthey, Sydney, Australia) to assess if more Au than contained in the soils could be solubilized. In some experiments cycloheximide ( $1000 \mu \mathrm{g} \mathrm{ml}^{-1}$ aqueous solution) was added to inhibit the growth of eukaryotes such as fungi, yeast, or algae, because they have been shown to actively adsorb complexed or colloidal $\mathrm{Au}$ complexes from solution (e.g., Korobushkina et al., 1983; Hosea et al., 1986; Savvaidis et al, 1998; Mukherjee et al., 2002; Nakajima, 2003). Five milliliters aqueous samples were aseptically collected from all experiments using sterile one-way plastic syringes (Terumo, Tokyo, Japan) and centrifuged at 15,000 rpm for $20 \mathrm{~min}$ in a microfuge (Eppendorf, Germany). The supernatant was decanted, filtered through a Whatman No. 4 paper filter, and analyzed using ICP-MS. Note that this method does not distinguish between dissolved and colloidal Au. This was cho- sen to measure how much of both forms of Au can be released from solid soil fractions, and thus to more closely represent what might happen in the field. In addition, the measured $\mathrm{Au}$ concentrations were too low to measure the speciation of Au reliably. Biologically active experiments contained field-fresh materials and were commenced within $24 \mathrm{~h}$ of arrival in the laboratory.

For the biologically inactive microcosms, i.e., sterilized control experiments, the solid materials were sterilized by autoclaving at $125^{\circ} \mathrm{C}$ and $1.1 \mathrm{~atm}$ for $1 \mathrm{~h}$ before sterile double deionized water was added; vein-quartz material had to be autoclaved three times to sterilize (Trevors, 1996). Sterility was tested optically using phase contrast microscopy and by plating of 1:10 (v:v) soil dilutions on nutrient agar plates (Oxoid, Basingstoke, UK) after the incubation; only those experiments that had remained sterile were used for further evaluation. It is possible that autoclaving affected the regolith materials, in particular how the $\mathrm{Au}$ is associated with the different fractions, so we checked for possible effects by analyzing field-fresh and autoclaved samples using the first three steps of a sequential leaching procedure (see below). No discernable changes to the fractionation of $\mathrm{Au}$ were detected in the autoclaved compared to the field-fresh materials. Repeatibility/reproducibility was established by running many experiments in duplicate or triplicate, as shown in Table 2. Biologically inactive microcosms were conducted in duplicate to reproducibly establish that no or significantly less $\mathrm{Au}$ was mobilized when no active microbiota were present. Microcosms with samples from July 2003 (triplicate) and October 2003 were conducted biologically active (Table 2) to determine the repeatability and variability of Au mobilization in samples collected at different sampling times.

\subsection{Total and sequential extractions}

Solid materials were analyzed for total Au concentrations and the fractionation of $\mathrm{Au}$ in the different solid phases. Total $\mathrm{Au}$ concentrations in all regolith materials were determined by digesting $1 \mathrm{~g}$ of sample for $24 \mathrm{~h}$ in $10 \mathrm{ml}$ concentrated aqua regia at $25^{\circ} \mathrm{C}$. The supernatant was filtered through a No. 4 Whatman paper filter and diluted with double deionized water to final $\mathrm{HNO}_{3}$ and $\mathrm{HCl}$ concentrations of $\approx 2$ and $0.7 \mathrm{vol} \%$, respectively. Sequential extractions were used to assess changes in the association of $\mathrm{Au}$ with different operationally defined solid soil fractions during incubation for two Ah-horizon microcosms incubated biologically active in triplicate, i.e., AJ3-a and $\mathrm{AJ} 3-\mathrm{a}+\mathrm{AuCl}_{4}{ }^{-}$amended with $100 \mu \mathrm{gg}^{-1}$ (d.w. soil) of $\mathrm{Au}$ as $\mathrm{AuCl}_{4}^{-}$. Solid samples were aseptically removed from $\mathrm{AJ} 3$-a after $0,10,20,30,40$, and 68 days of incubation, and after 10 days from $\mathrm{AJ} 3-\mathrm{a}+\mathrm{AuCl}_{4}{ }^{-}$. The latter experiment was to test for the capacity of the soil to adsorb $\mathrm{Au}$ and to determine the fractionation of the adsorbed $\mathrm{Au}$ to the solid soil fractions. The sequential leaching procedure used in this study was developed by Reith et al. (2005) based on methods used in previous studies (e.g., 
Table 2

Sampling times, incubation conditions, and analyses in microcosm experiments conducted with soil- and quartz-vein materials from the Tomakin Park Gold Mine

\begin{tabular}{|c|c|c|c|c|c|c|c|c|c|c|c|c|c|}
\hline \multirow[t]{2}{*}{ Microcosm } & \multicolumn{3}{|c|}{ Sampling material } & \multicolumn{3}{|c|}{ Sampling date } & \multicolumn{2}{|c|}{$\begin{array}{l}\text { Biological } \\
\text { activity }\end{array}$} & \multicolumn{4}{|c|}{ Amendments and conditions } & \multirow[t]{2}{*}{ Analyses } \\
\hline & $\begin{array}{l}\text { Ah-horizon } \\
\text { (A) }\end{array}$ & $\begin{array}{l}\text { B-horizon } \\
\text { (B) }\end{array}$ & $\begin{array}{l}\text { Quartz } \\
\text { (Q) }\end{array}$ & $\begin{array}{l}\text { June } 2002 \\
(\mathrm{~J} 2)\end{array}$ & $\begin{array}{l}\text { July } 2003 \\
\text { (J3) }\end{array}$ & $\begin{array}{l}\text { October } 2003 \\
\text { (O3) }\end{array}$ & $\begin{array}{l}\text { Active } \\
\text { (a) }\end{array}$ & $\begin{array}{l}\text { Inactive } \\
\text { (i) }\end{array}$ & None & $\begin{array}{l}\text { Au pellets } \\
(+\mathrm{Au})\end{array}$ & $\begin{array}{l}\text { Cyclo-heximide } \\
(+\mathrm{C})\end{array}$ & Other & \\
\hline $\mathrm{AJ} 2-\mathrm{a}$ & $\mathrm{X}$ & & & $\mathrm{X}$ & & & $\mathrm{X}$ & & $\mathrm{X}$ & & & & $\mathrm{pH}, \mathrm{O}_{2}$, cell numbers \\
\hline AJ2-i & $\mathrm{X}$ & & & $\mathrm{X}$ & & & & $\mathrm{X}$ & $\mathrm{X}$ & & & Duplicate & \\
\hline $\mathrm{AJ} 2-\mathrm{a}+\mathrm{C}$ & $\mathrm{X}$ & & & $\mathrm{X}$ & & & $\mathrm{X}$ & & & & $\mathrm{X}$ & & $\mathrm{pH}$ \\
\hline $\mathrm{AJ} 2-\mathrm{i}+\mathrm{C}$ & $\mathrm{X}$ & & & $\mathrm{X}$ & & & & $\mathrm{X}$ & & & $\mathrm{X}$ & Duplicate & $\mathrm{pH}$ \\
\hline $\mathrm{AJ} 2-\mathrm{a}+\mathrm{Au}$ & $\mathrm{X}$ & & & $\mathrm{X}$ & & & $\mathrm{X}$ & & & $\mathrm{X}$ & & & $\mathrm{pH}$ \\
\hline $\mathrm{AJ} 2-\mathrm{i}+\mathrm{Au}$ & $\mathrm{X}$ & & & $\mathrm{X}$ & & & & $\mathrm{X}$ & & $\mathrm{X}$ & & Duplicate & $\mathrm{pH}$ \\
\hline $\mathrm{AJ} 2-\mathrm{a}+\mathrm{Au}-\mathrm{an}$ & $\mathrm{X}$ & & & $\mathrm{X}$ & & & $\mathrm{X}$ & & & & & Anoxic (an) & \\
\hline BJ2-a & & $\mathrm{X}$ & & $\mathrm{X}$ & & & $\mathrm{X}$ & & $\mathrm{X}$ & & & & $\mathrm{pH}, \mathrm{O}_{2}$, cell numbers \\
\hline BJ2-i & & $\mathrm{X}$ & & $\mathrm{X}$ & & & & $\mathrm{X}$ & $\mathrm{X}$ & & & Duplicate & $\mathrm{pH}$ \\
\hline $\mathrm{BJ} 2-\mathrm{a}+\mathrm{Au}$ & & $\mathrm{X}$ & & $\mathrm{X}$ & & & $\mathrm{X}$ & & & $\mathrm{X}$ & & & $\mathrm{pH}$ \\
\hline $\mathrm{BJ} 2-\mathrm{i}+\mathrm{Au}$ & & $\mathrm{X}$ & & $\mathrm{X}$ & & & & $\mathrm{X}$ & & $\mathrm{X}$ & & Duplicate & $\mathrm{pH}$ \\
\hline BJ2-a + Au-an & $\mathrm{X}$ & & & $\mathrm{X}$ & & & $\mathrm{X}$ & & & $\mathrm{X}$ & & Anoxic (an) & \\
\hline QJ2-a & & & $\mathrm{X}$ & $\mathrm{X}$ & & & & & & & & & $\mathrm{pH}$, cell numbers \\
\hline QJ2-i & & & $\mathrm{X}$ & $\mathrm{X}$ & & & & & & & & Duplicate & $\mathrm{pH}$ \\
\hline $\mathrm{AJ} 3-\mathrm{a}$ & $\mathrm{X}$ & & & & $\mathrm{X}$ & & $\mathrm{X}$ & & $\mathrm{X}$ & & & Triplicate & AAS, CLPP, Sel. Leach. \\
\hline $\mathrm{AJ} 3-\mathrm{a}+\mathrm{Au}$ & $\mathrm{X}$ & & & & $\mathrm{X}$ & & $\mathrm{X}$ & & & $\mathrm{X}$ & & & CLPP \\
\hline $\mathrm{AJ} 3-\mathrm{a}+\mathrm{AuCl}_{4}^{-}$ & $\mathrm{X}$ & & & & $\mathrm{X}$ & & $\mathrm{X}$ & & & & & Triplicate, $+\mathrm{AuCl}_{4}^{-}$ & Sel. Leach. \\
\hline A100J3-a & $\mathrm{A} 100$ & & & & $\mathrm{X}$ & & $\mathrm{X}$ & & $\mathrm{X}$ & & & & CLPP \\
\hline $\mathrm{A} 100 \mathrm{~J} 3-\mathrm{a}+\mathrm{Au}$ & A100 & & & & $\mathrm{X}$ & & $\mathrm{X}$ & & & $\mathrm{X}$ & & Triplicate & Biofilm \\
\hline $\mathrm{BJ} 3-\mathrm{a}$ & & $\mathrm{X}$ & & & $\mathrm{X}$ & & $X$ & & $X$ & & & & CLPP \\
\hline B100J3-a & & $\mathrm{B} 100$ & & & $\mathrm{X}$ & & $\mathrm{X}$ & & & $\mathrm{X}$ & & & CLPP \\
\hline $\mathrm{AO} 3-\mathrm{a}+\mathrm{Au}$ & $\mathrm{X}$ & & & & & $\mathrm{X}$ & $\mathrm{X}$ & & & $\mathrm{X}$ & & $30{ }^{\circ} \mathrm{C}$ & \\
\hline
\end{tabular}


Chao, 1984; Hall et al., 1995, 1998; Xueqiu, 1998; Gray et al., 1999). The reagent and operationally defined fraction for each extraction was: double deionized water for the water-soluble fraction, $1 \mathrm{M}$ ammonium acetate $\left(\mathrm{NH}_{4} \mathrm{OAc}\right)$ for the exchangeable, clay- and carbonate-bound fraction, $1 \%$ sodium pyrophosphate $\left(\mathrm{Na}_{4} \mathrm{P}_{2} \mathrm{O}_{7}\right)$ for the organic fraction, $0.25 \mathrm{M}$ hydroxylamine hydrochloride $\left(\mathrm{NH}_{2} \mathrm{OH} \cdot \mathrm{HCl}\right)$ in $0.25 \mathrm{M}$ hydrochloric acid $(\mathrm{HCl})$ for the amorphous $\mathrm{Fe}$ and $\mathrm{Mn}$-oxides fraction, and $4 \mathrm{M} \mathrm{HCl}$ for the crystalline Fe-oxide fraction. The procedure for each extraction was: (i) $1 \mathrm{~g}$ of sample was added to $15 \mathrm{ml}$ Falcon tubes; (ii) $10 \mathrm{ml}$ of leaching solution was added; (iii) the tubes were shaken for $6 \mathrm{~h}$ at $25^{\circ} \mathrm{C}$; (iv) the tubes were centrifuged for $30 \mathrm{~min}$ at $4000 \mathrm{~g}$ after each extraction step; (v) the supernatant was decanted and filtered through Whatman No. 4 paper; (vi) the residue dried in air overnight at 60 $70{ }^{\circ} \mathrm{C}$; (vii) the next leaching solution was added; and (viii) steps 3-7 were repeated for each leaching step. All extract solutions were stored in the dark at $-20^{\circ} \mathrm{C}$ until analysis. Note that the extractions are operationally defined and may not necessarily reflect the fractions that are intended in any of these methods (Chao, 1984; Hall et al., 1995, 1998; Xueqiu, 1998; Gray et al., 1999); however, because our experiments were conducted in triplicate, we were able to discern statistical differences between the results of the different extractions. To evaluate if the observed differences between the analogous extractions on days $0,10,20,30,40$, and 68 were significant, two-tailed $t$ tests were performed at significance levels of $p=0.05$ using the Statistical Package for Social Sciences (SPSS) version 11.0 (SPSS, 2001).

\subsection{Chemical analysis}

Gold in the liquid samples was measured using an Agilent 7500S ICP-MS, equipped with a concentric nebulizer and an automatic sampler. The detection limit for $\mathrm{Au}$ was $2.8 \mathrm{ng} \mathrm{L}^{-1}$ and analytical precision lay within $5 \%$. Total carbon, $C_{\text {tot }}$, and total nitrogen, $N_{\text {tot }}$, contents of Ahand B-horizon samples were measured using a Leco CNS 2000 element analyzer. Minerals were identified and their abundances determined at Geoscience Australia using XRD on powdered samples using the SIROQUANT software following the procedures outlined in Taylor (1991). Size fraction analysis of the $<2 \mathrm{~mm}$ Ah- and B-horizon samples was conducted using the pipette method (USDA Method 3A1, 1996). The concentration of free amino acids in soil solutions was measured in selected experiments by a commercial laboratory (Australian Proteome Facility, Sydney, Australia) using high-pressure liquid chromatography (HPLC). The $\mathrm{pH}$ values of the liquid samples were measured with an Activon $\mathrm{pH}$ electrode and meter.

\subsection{Microbiological analysis}

\subsubsection{Bacterial numbers determined by direct cell counts}

During the incubation of three unamended microcosms, i.e., $\mathrm{AJ} 2-\mathrm{a}, \mathrm{BJ} 2-\mathrm{a}$, and $\mathrm{QJ} 2$-a slurry samples were aseptically collected for direct optical cell counts. Cells were counted with using a haemocytometer with a Thoma counting chamber (Assistent, Germany) and a phase contrast microscope without previous dyeing. Samples were diluted $10^{3}-10^{4}$ times with sterile $0.9 \% \mathrm{NaCl}$ solution so that the number of organisms counted in a single square $\approx 2-12$ cells. One hundred of the 400 fields were counted for each sample, and then the average bacterial number and standard error for each sample was calculated.

\subsubsection{Analysis of biofilms on Au pellets}

To assess the formation of biofilms on the added $\mathrm{Au}$ pellets, pellets from the biologically active experiments, i.e., $\mathrm{AJ} 2-\mathrm{a}+\mathrm{Au}, \mathrm{AJ} 3-\mathrm{a}+\mathrm{Au}$, and $\mathrm{A} 100 \mathrm{~J} 3-\mathrm{a}+\mathrm{Au}$, were aseptically collected after 70 days of incubation and thoroughly rinsed with sterile deionized water. One pellet from each experiment or replicate was then mounted on stubs using carbon tape and examined uncoated with a Cambridge S360 scanning electron microscope (SEM) operated at $20 \mathrm{kV}$ and $\approx 20 \mathrm{~mm}$ working distance, and equipped with a Tracor Northern EDXA detector. To study the composition of the coatings discovered on the $\mathrm{Au}$ pellets, samples were analyzed with a JEOL JSM 6400 scanning electron microscope equipped with an Oxford Instruments light element EDXA detector and Link ISIS software. The second Au pellet from each experiment or replicate was stained using the nucleic-acid-specific fluorochrome 4',6'-diamidino-2-phenylindole hydrochloride (DAPI; Sigma, St. Louis, MO; Larsson et al., 1996). The samples were stained on ice with $1 \mathrm{ml}$ of $10 \mu \mathrm{ml}^{-1}$ DAPI solution for $20 \mathrm{~min}$ and then washed with deionized water and air dried. The stained biofilms were examined with a Leica TCS-SP2-UV confocal laser microscope with Leica imaging software (Leica, Wetzlar, Germany).

\subsubsection{Community structure analysis}

The community-level physiological profiling method (CLPP) using BIOLOG ${ }^{\mathrm{TM}}$ Ecoplates (BIOLOG, Hayward, CA, USA) was used in this study to evaluate changes in the culturable, heterotrophic, and aerobic bacterial community in the soil samples during incubation of the microcosms. CLPP fingerprints were obtained according to a method developed by Garland and Mills (1991), which has successfully been used to differentiate between microbial activity in soil samples subject to different environmental influences such as heavy metal contamination, and to subsequently infer microbial community population changes due to different substrate utilization profiles (e.g., Garland and Mills, 1991; Mueller et al., 2001). BIOLOG ${ }^{\mathrm{TM}}$ Ecoplates contain 31 carbon sources (three replicates for each) with tetrazolium redox dye and one control well containing the dye but no carbon source. Samples for CLPP fingerprinting were taken from five microcosms, i.e., AJ3-a, AJ3-a + Au A100J3-a, BJ3-a, and B100J3-a (Table 3), on day $0,10,20,30,40$, and 68 of the incubation. One milliliter 
Table 3

Concentrations of free amino acids in solutions from microcosm AJ3-a

\begin{tabular}{llcl}
\hline Amino acid & \multicolumn{2}{l}{ Concentration $(\mu \mathrm{M})$} & \\
\cline { 2 - 4 } & Day 0 & Day 20 & Day 50 \\
\hline Aspartic acid & 1.3 & 3.6 & n.d. \\
Serine & 1.4 & 4.2 & 2.2 \\
Glutamic acid & n.d. & 6.0 & n.d. \\
Glycine & 3.9 & 9.3 & 3.7 \\
Glutamine & n.d. & 0.9 & n.d. \\
Arginine & n.d. & 2.1 & n.d. \\
Threonine & n.d. & 2.1 & n.d. \\
Alanine & 1.4 & 18.3 & 1.6 \\
Tyrosine & n.d. & 1.9 & n.d. \\
Valine & 0.5 & 6.9 & 0.5 \\
Isoleucine & n.d. & 3.1 & n.d. \\
Leucine & n.d. & 2.8 & n.d. \\
Phenylalanine & n.d. & 3.0 & n.d. \\
Total & 8.5 & 64.2 & 8.0 \\
\hline
\end{tabular}

${ }^{\text {a }}$ n.d., not detected.

of soil slurry was aseptically removed from the microcosms and diluted in $25 \mathrm{ml}$ of $0.9 \mathrm{wt} \% \mathrm{NaCl}$ solution, to make a final dilution of 1:100. BIOLOG ${ }^{\mathrm{TM}}$ Ecoplates were inoculated with $125 \mu \mathrm{l}$ of sample per well and incubated at $25^{\circ} \mathrm{C}$ in the dark for $120 \mathrm{~h}$ (BIOLOG, Hayward, USA). The absorbance of the plates were read with a Biolog microplate reader $(590 \mathrm{~nm})$ at $6 \mathrm{~h}$ intervals for $60 \mathrm{~h}$ and then at $12 \mathrm{~h}$ intervals for a further $60 \mathrm{~h}$.

The community-level response was separated into two major components: (i) the overall rate of color development; and (ii) the emerging pattern of substrate utilization. The overall rate can be estimated by the rate of AWCD, and is a function of the inoculum density (Garland, 1996). In this study, the AWCD was measured over time and used as a measure of total activity. To eliminate weak false positive responses a threshold of 0.1 absorbance units was used (Garland, 1996).

To analyze for similarities and differences in the patterns of the microbial responses, a variety of multivariate statistical approaches have been used (e.g., Hitzl et al., 1997; Preston-Mafham et al., 2002; Yan et al., 2000). In this study, we calculated the area under the absorbance curve versus time curve for every well using the trapezoidal approximation to the area under the curve according to Guckert et al. (1996). Only area values greater than 1 were used for further statistical analysis. Using this method differences in lag times, rates of increase and maximum optical densities can be accurately assessed, making it a robust method to study differences in patterns of the microbial responses (Guckert et al., 1996). A principal component analysis with Kaiser normalization was used to evaluate further differences in patterns. Several methods of matrix rotations, i.e., varimax, quartimax, equamax, and promax, were tried, but varimax rotation with Kaiser normalization was found to be the most effective in separating the data. All calculations were made using SPSS version 11.0.

\section{Results and discussion}

This section consists of following subsections: (i) solubilization of $\mathrm{Au}$ in biologically active and inactive (sterilized) microcosms; (ii) analysis of the biofilms growing on Au pellets incubated in biologically active microcosms; (iii) changes occurring in the structure of the heterotrophic, aerobic bacterial communities in selected auriferous and non-auriferous soil microcosms during the incubation; and (iv) a discussion on the implications of microbial processes on behavior of and exploration for $\mathrm{Au}$ in the regolith.

\subsection{Solubilization of $\mathrm{Au}$ in microcosm experiments}

In general, $\mathrm{Au}$ was solubilized in all biologically active microcosms with auriferous soils (Figs. 2-4). Gold was detectable in solution within 4-30 days of the start of the incubation, generally reached maximum concentrations between days 30 and 45, decreased thereafter and in many cases no $\mathrm{Au}$ was detected in solution by the end of the experiments (Figs. 2A and B, 3, and $4 \mathrm{~A}$ and B). In the biologically inactive microcosm, Au concentrations in solution were typically below detection or much lower than in the equivalent biologically active microcosms (Figs. 2A and $\mathrm{B}, 4 \mathrm{~A}$ and $\mathrm{B})$.

\subsubsection{Gold solubilization in microcosms of the Ah-horizon}

To determine the effect of resident microbiota on the solubilization of $\mathrm{Au}$, the concentrations of $\mathrm{Au}$ in solution in unamended biologically active and inactive microcosms, i.e., AJ2-a and $\mathrm{AJ} 2-\mathrm{i}$, respectively, were measured. In AJ2-a $65 \mathrm{ngg}^{-1}$ (d.w. soil) of Au was detected in solution at day 4 and then none until day 44 and day 45 where 1134 and $534 \mathrm{ngg}^{-1}$ (d.w. soil) were detected, respectively (Fig. 2A). No Au was detected in solution between 45 days and the end of the experiment at day 70. Based on the aqua regia digests conducted with soils from $\mathrm{AJ} 2-\mathrm{a}$, that yielded total $\mathrm{Au}$ concentrations of $1453 \mathrm{ngg}^{-1}$ (d.w. soil), this amounts to a maximum of $\approx 80 \mathrm{wt} . \%$ of $\mathrm{Au}$ dissolved at day 44. Gold was not detected in the solution during the incubation in either of the duplicates of $\mathrm{AJ} 2-\mathrm{i}$.

The addition of cycloheximide, designed to inhibit the growth of eukaryotes, e.g., fungi, yeasts, and algae, resulted in an early increase in solubilized Au relative to the unamended equivalent microcosms, but the pattern of solubilization was similar. Gold was detected in solution in $\mathrm{AJ} 2-\mathrm{a}+\mathrm{C}$ during the first 40 days in concentration of 34-260 $\mathrm{ng} \mathrm{g}^{-1}$ (d.w. soil); the maximum Au concentration was $664 \mathrm{ngg}^{-1}$ (d.w. soil) at day 45 (Fig. 2A). Gold was not detected in the solution in either of the duplicates of the AJ2-i $+\mathrm{C}$ microcosm (Fig. 2A). The early release of $\mathrm{Au}$ suggests that $\mathrm{Au}$ may have been constantly solubilized during the first 40-50 days of the incubation in all microcosms, but that active eukaryotes re-adsorb Au rapidly.

Gold solubilization patterns in experiments amended with Au pellets were similar those detected in unamended 

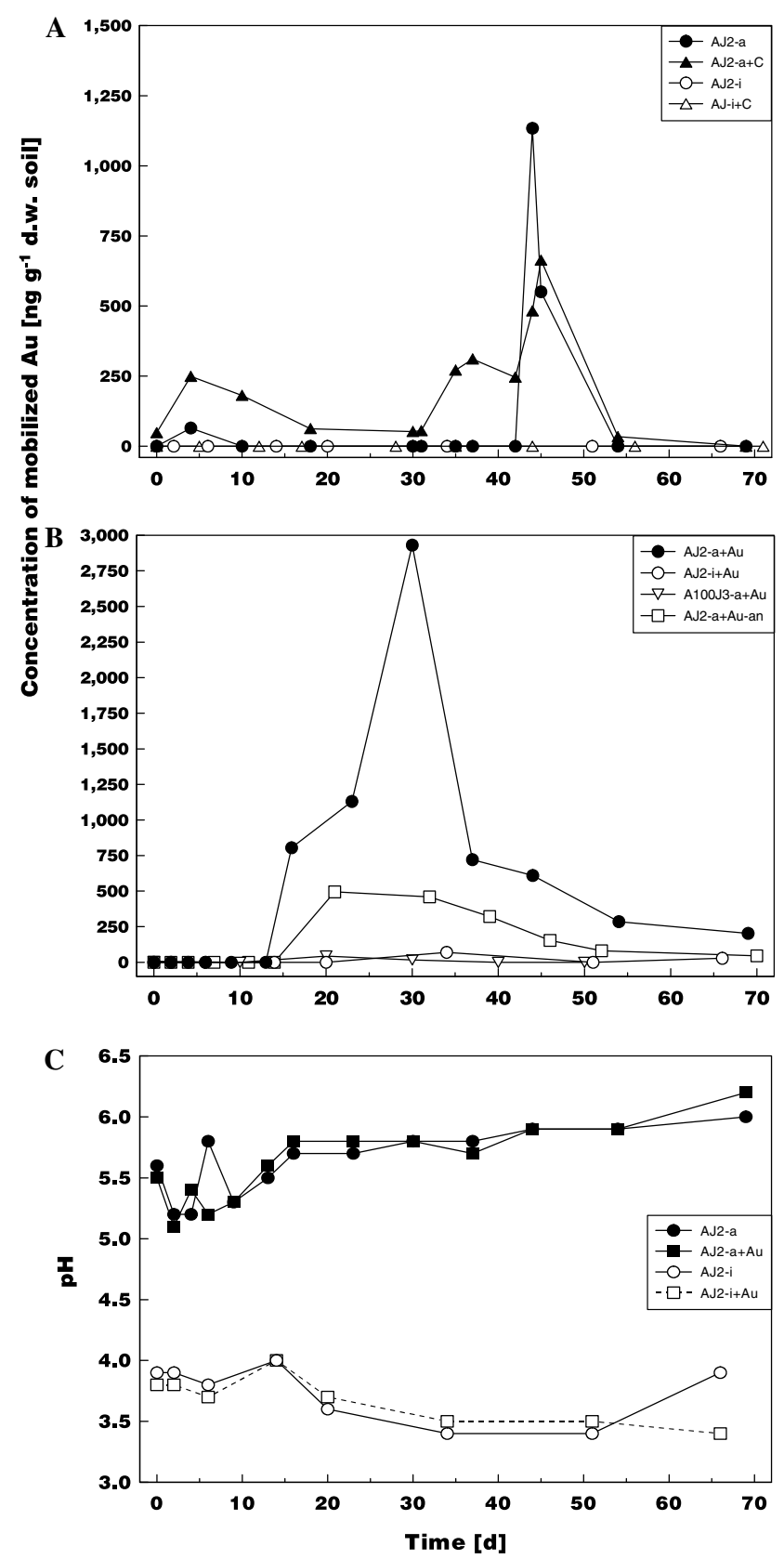

Fig. 2. Concentration of solubilized $\mathrm{Au}(\mathrm{A}$ and $\mathrm{B})$ and $\mathrm{pH}(\mathrm{C})$ in solutions from microcosms incubated biologically active or inactive (sterilized) with samples from the Ah-horizon collected in June 2002.

microcosms, although $\mathrm{Au}$ was solubilized earlier and in higher concentrations (Fig. 2B). In $\mathrm{AJ} 2-\mathrm{a}+\mathrm{Au}, \mathrm{Au}$ was detected in solution after 14 days of incubation and reached a maximum concentration of $2930 \mathrm{ngg}^{-1}$ (d.w. soil) of Au at day 30 (Fig. 2B). The maximum was approximately three times higher than in the unamended microcosm and was approximately twice the concentration of $\mathrm{Au}$ contained in the soil samples indicating that the microbiota were able to solubilize more Au than was present in the soils by mobilizing it from the added Au pellets.

Anoxic microzones are generally present in oxic soils (e.g., van der Lee et al., 1999) and anaerobic bacteria con- stitute $\approx 10 \%$ of the total culturable bacterial community in oxic soils (e.g., Küsel et al., 1999; Skinner, 1975). Therefore, an experiment (AJ2-a + Au-an) was conducted under anoxic conditions to compare its results to those of the equivalent oxic experiment; amendment with $\mathrm{Au}$ pellets was chosen to potentially maximize the effect. The results of an anoxic microcosm indicate that the anaerobic microbiota are capable of solubilizing the Au that is disseminated in the solid soil fractions, but that in contrast to the oxic microcosm the organisms were not able to solubilized $\mathrm{Au}$ from the added $\mathrm{Au}$ pellets. In the anoxic experiment, the pattern of $\mathrm{Au}$ solubilization was similar than in the equivalent oxic experiment; however, the maximum concentrations of solubilized $\mathrm{Au}$ were lower, i.e., $481 \mathrm{ngg}^{-1}$ (d.w. soil) compared to $2930 \mathrm{ngg}^{-1}$ (d.w. soil), respectively (Fig. 2B).

The microcosms using samples with background $\mathrm{Au}$ concentrations (A100) displayed no Au solubilization, even when they were amended with Au pellets. The unamended A100 sample contained little Au that could be mobilized, i.e., $2-3 \mathrm{ng}$ of $\mathrm{Au} \mathrm{g}^{-1}$ (d.w soil), and in A100J3-a + Au less than $70 \mathrm{ngg}^{-1}$ (d.w. soil) of Au was solubilized, which lay within the range of the sterile control experiment (Fig. 2B). The result indicates that the appropriate microorganisms were either not present or not active in the experiment.

The variation of the solution $\mathrm{pH}$ occurring between biologically active and inactive microcosms may influence the observed solubilization patterns of $\mathrm{Au}$. To account for this, the $\mathrm{pH}$ values were measured in several biologically active and inactive microcosms during the incubation (Fig. 2C). At the start of the experiment, the $\mathrm{pH}$ lay between 3.5 and 4.0 in the autoclaved controls and was throughout the incubation 1.0-1.5 U lower compared to the biologically active microcosms (Fig. 2C). A lowering of $\mathrm{pH}$ in autoclaved soil was observed in other studies (e.g., Shaw et al., 1999), but did in our experiments apparently not enhance the solubilization of $\mathrm{Au}$.

Differences in $\mathrm{Au}$ solubilization in microcosms with samples from different sampling times were detected and

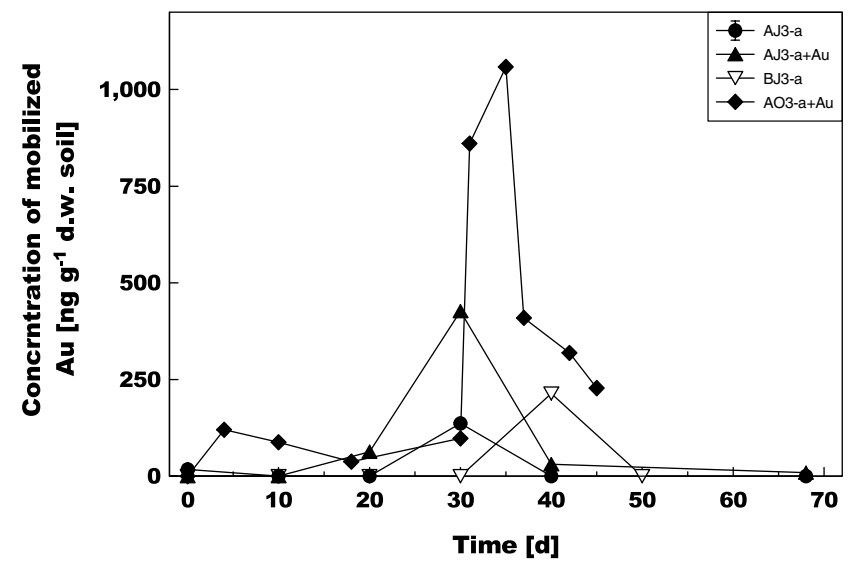

Fig. 3. Concentration of solubilized $\mathrm{Au}$ in solutions from microcosms incubated biologically active with samples from the Ah- and B-horizon collected in July and October 2003. 
may be the result of differences in the community structures and/or activity of the resident microbiota. Biologically active microcosms were conducted with Ah-horizon samples collected in July and October 2003, i.e., AJ3-a, AJ3$\mathrm{a}+\mathrm{Au}, \mathrm{AO} 3-\mathrm{a}+\mathrm{Au}$ (Fig. 3). The solubilization of Au followed a similar pattern than in the equivalent biologically active microcosms from June 2002, however, the timing of $\mathrm{Au}$ release and its concentration generally differed (Fig. 3). In AJ3-a a Au concentration of $136 \pm 2 \mathrm{ngg}^{-1}$ (d.w. soil) was detected in solution after 30 days, Au in solution was not detected at the other sampling times (Figs. 3 and 5). AJ3-a $+\mathrm{Au}$ yielded much lower maximum concentrations of $\mathrm{Au}$ in solution, i.e., $427 \mathrm{ng} \mathrm{g}^{-1}$ (d.w. soil),
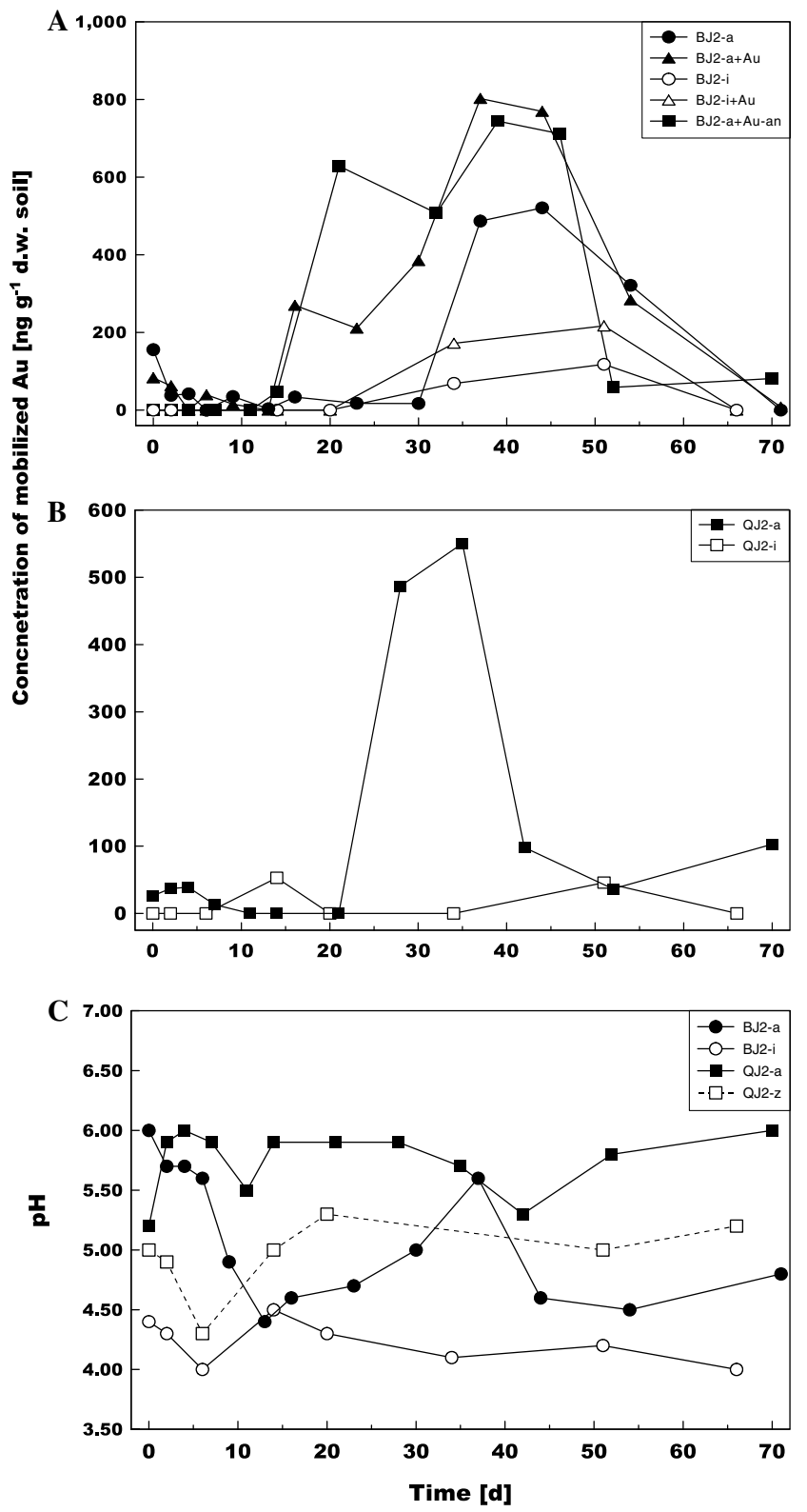

Fig. 4. Concentration of solubilized $\mathrm{Au}(\mathrm{A}$ and $\mathrm{B})$ and $\mathrm{pH}(\mathrm{C})$ in solutions from microcosms incubated biologically active or inactive (sterilized) with samples from the B-horizon (A) and the quartz-vein material (B) collected in June 2002. compared to $\mathrm{AJ} 2-\mathrm{a}+\mathrm{Au}$. $\mathrm{AO} 3-\mathrm{a}+\mathrm{Au}$ was incubated at $30{ }^{\circ} \mathrm{C}$ and $\mathrm{Au}$ was detected in all solution samples taken after day 4 day, reaching a maximum of $1058 \mathrm{ngg}^{-1}$ (d.w. soil) after 35 days, and then decreasing to $\approx 200 \mathrm{ngg}^{-1}$ (d.w. soil) at the end of the incubation at day 45 .

\subsubsection{Gold solubilization in microcosms of the B-horizon}

In the biologically active microcosms with B-horizon samples, similar solubilization- and re-precipitation patterns were detected compared to the corresponding Ah-horizon experiments (Fig. 4A). Gold concentrations in solution were much higher in biologically active, i.e., BJ2$\mathrm{a}$ and $\mathrm{BJ} 2-\mathrm{a}+\mathrm{Au}$, compared to inactive microcosms, i.e., $\mathrm{BJ} 2-\mathrm{i}$ and $\mathrm{BJ} 2-\mathrm{i}$, indicating an effect of the resident microbiota on the solubilization of $\mathrm{Au}$. The highest concentrations of $\mathrm{Au}$ in solution in $\mathrm{BJ} 2 \mathrm{-a} \mathrm{Au}$ were detected at days 37 and 44 , i.e., 486 and $521 \mathrm{ng} \mathrm{g}^{-1}$ (d.w. soil), respectively (Fig. 4A). The maximum concentration represents $80 \mathrm{wt} . \%$ of the total $\mathrm{Au}$ content, i.e., $652 \mathrm{ng} \mathrm{g}^{-1}$ (d.w. soil), in solution. BJ2-i displayed a maximum $\mathrm{Au}$ concentration in solution in one of the duplicates of $117 \mathrm{ng} \mathrm{g}^{-1}$ (d.w. soil) at day 51 , but generally no or much lower Au concentration were detected (Fig. 4A).

In $\mathrm{BJ} 2-\mathrm{a}+\mathrm{Au}$ we observed a similar pattern as in the unamended experiments, although $\mathrm{Au}$ in solution was detected earlier at day 15 . The maximum $\mathrm{Au}$ concentration in solution in $\mathrm{BJ} 2-\mathrm{a}+\mathrm{Au}$ was $802 \mathrm{ngg}^{-1}$ (d.w. soil). One of the duplicates in sterile control experiment, $\mathrm{BJ} 2-\mathrm{i}+\mathrm{Au}$, had up to $217 \mathrm{ngg}^{-1}$ (d.w. soil) Au in solution (day 51; Fig. 4A), but typically had much lower values, and in all cases less than in the equivalent biologically active experiment.

$\mathrm{BJ} 2-\mathrm{a}+\mathrm{Au}-\mathrm{an}$ was run under anoxic conditions and the results indicate that the anaerobic microbiota of the B-horizon similarly to those of the Ah-horizon appears capable of solubilizing Au. In B100J3-a (background sample) $\mathrm{Au}$ was detected in the solution after 14 days of incubation, from day 20 to day 50 the $\mathrm{Au}$ concentration in solution fluctuated between 500 and $730 \mathrm{ngg}^{-1}$ (d.w. soil), after which it decreased sharply to $\approx 50 \mathrm{ng} \mathrm{g}^{-1}$ d.w. soil between day 50 and 52 (Fig. 4A). BJ3-a showed that the mobilization of $\mathrm{Au}$ in the B-horizon was repeatable with samples collected at different times; $213 \mathrm{ngg}^{-1}$ (d.w. soil) of $\mathrm{Au}$ was mobilized at day 40 of the incubation (Fig. 3). The $\mathrm{pH}$ values, which were $1.5 \mathrm{U}$ lower and changed little during the incubation time in the biologically inactive compared to active microcosms, did not lead to an enhanced Au solubilization (Fig. 4C).

\subsubsection{Solubilization of Au in microcosms with vein-quartz material}

The solubilization and precipitation pattern detected in the vein-quartz microcosms was generally similar to those detected in Ah- and B-horizon microcosms (Fig. 4B). Gold was detected in solution in the biologically active veinquartz microcosm, i.e., QJ2-a, during the first days of 


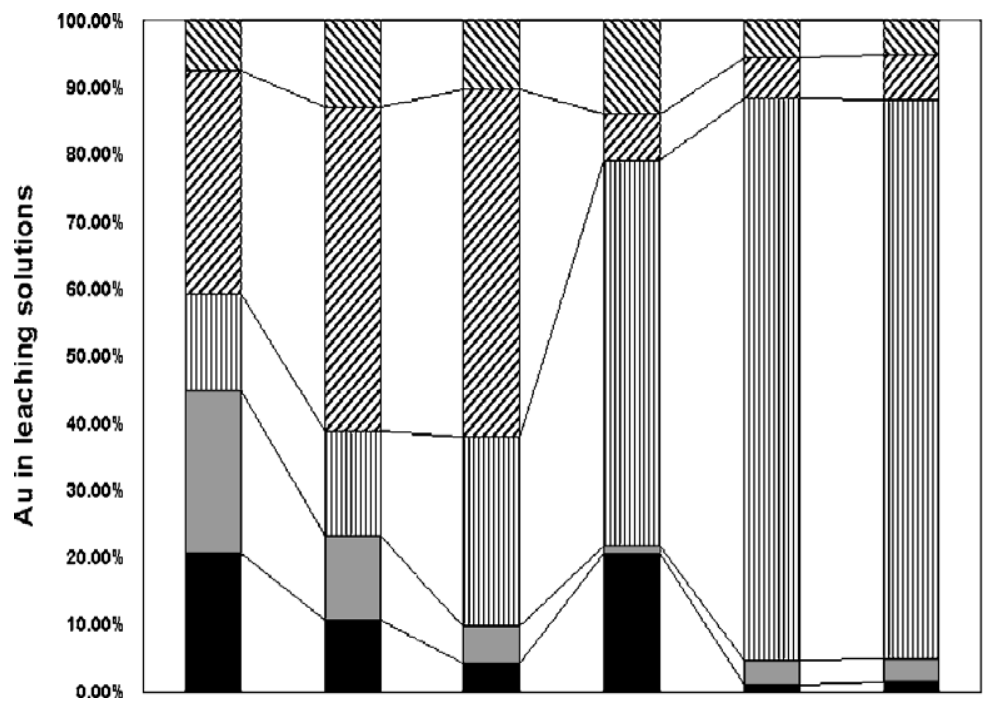

\begin{tabular}{|c|c|c|c|c|c|c|}
\hline & \multicolumn{6}{|c|}{ Au [ng g ${ }^{-1}$ d.w. soil] } \\
\hline & Day 0 & Day 10 & Day 20 & Day 30 & Day 40 & Day 68 \\
\hline $\begin{array}{l}\text { Extraction } 1 \\
\text { (water, }\end{array}$ & $38( \pm 12)$ & $70( \pm 23)$ & $\begin{array}{c}60( \pm 22) \\
e\end{array}$ & $\begin{array}{c}62( \pm 14) \\
f\end{array}$ & $\begin{array}{c}30( \pm 6) \\
c\end{array}$ & $\begin{array}{c}27( \pm 1) \\
d\end{array}$ \\
\hline $\begin{array}{l}\text { Extraction } 2 \\
\left(\mathrm{NH}_{4} \mathrm{Oac}, \mathbf{2}\right)\end{array}$ & $\begin{array}{c}170( \pm 11) \\
b, c, d, e, f\end{array}$ & $\begin{array}{c}263( \pm 14) \\
a, d, e, f\end{array}$ & $\begin{array}{c}301( \pm 43) \\
a, d, e, f\end{array}$ & $\begin{array}{c}31( \pm 2) \\
a, b, c\end{array}$ & $\begin{array}{c}32( \pm 3) \\
a, b, c\end{array}$ & $\begin{array}{c}34( \pm 1) \\
a, b, c\end{array}$ \\
\hline $\begin{array}{l}\text { Extraction } 3 \\
\left(\mathrm{Na}_{4} \mathrm{P}_{2} \mathrm{O}_{7}, \text {, }\right)\end{array}$ & $\begin{array}{c}73( \pm 84) \\
e, f\end{array}$ & $\begin{array}{c}83( \pm 58) \\
d, e, f\end{array}$ & $\begin{array}{c}163( \pm 13) \\
d, e, f\end{array}$ & $\begin{array}{c}257( \pm 6) \\
b, c, e, f\end{array}$ & $\begin{array}{c}452( \pm 13) \\
a, b, c, d\end{array}$ & $\begin{array}{c}430( \pm 1) \\
a, b, c, d\end{array}$ \\
\hline $\begin{array}{l}\text { Extraction } 4 \\
\left(\mathrm{NH}_{2} \mathrm{OH} . \mathrm{HCl}, \mathrm{L}\right.\end{array}$ & $\begin{array}{c}122( \pm 10) \\
d, e, f\end{array}$ & $68( \pm 39)$ & $33( \pm 36)$ & $\begin{array}{c}5( \pm 4) \\
a, e\end{array}$ & $\begin{array}{c}20( \pm 2) \\
a, d\end{array}$ & $\begin{array}{c}18( \pm 6) \\
a\end{array}$ \\
\hline $\begin{array}{l}\text { Extraction } 5 \\
(\mathrm{HCl}, \square)\end{array}$ & $\begin{array}{c}105( \pm 18) \\
c, e, f\end{array}$ & $58( \pm 35)$ & $\begin{array}{c}24( \pm 11) \\
a\end{array}$ & $93( \pm 69)$ & $\begin{array}{c}6( \pm 1) \\
a, f\end{array}$ & $\begin{array}{c}8( \pm 1) \\
a, e\end{array}$ \\
\hline Soil solution & $\begin{array}{l}0 \\
d\end{array}$ & $\begin{array}{l}0 \\
d\end{array}$ & $\begin{array}{l}0 \\
d\end{array}$ & $\begin{array}{l}136( \pm 2) \\
a, b, c, e, f\end{array}$ & $\begin{array}{l}0 \\
d\end{array}$ & $\begin{array}{l}0 \\
d\end{array}$ \\
\hline Total & $509( \pm 87)$ & $542( \pm 51)$ & $582( \pm 21)$ & $574( \pm 66)$ & $540( \pm 55)$ & $519( \pm 7)$ \\
\hline $\begin{array}{ll}\text { a: } & \text { signific } \\
\text { b: } & \text { signific } \\
\text { c: } & \text { signific } \\
\text { d: } & \text { signific } \\
\text { e: } & \text { signific } \\
\text { f: } & \text { signific }\end{array}$ & $\begin{array}{l}\text { different fro } \\
\text { different frc } \\
\text { different frc } \\
\text { different frc } \\
\text { different frc } \\
\text { different fro }\end{array}$ & $\begin{array}{l}m \text { analogous } \\
m \text { analogous } \\
m \text { analogous } \\
m \text { analogous } \\
m \text { analogous } \\
m \text { analogous }\end{array}$ & $\begin{array}{l}\text { extraction on } \\
\text { extraction on } \\
\text { extraction on } \\
\text { extraction on } \\
\text { extraction on } \\
\text { extraction on }\end{array}$ & $\begin{array}{l}\text { day } 0(p=0 . \\
\text { day } 10(p=0 \\
\text { day } 20(p=0 \\
\text { day } 30(p=0 \\
\text { day } 40(p=0 \\
\text { day } 68(p=0\end{array}$ & $\begin{array}{l}5) . \\
55) . \\
55) . \\
55) . \\
55) .\end{array}$ & \\
\hline
\end{tabular}

Fig. 5. Association of Au with different solid soil fractions of the Ah-horizon and the aqueous solution in microcosm AJ3-a (Table 2; Fig. 2). The five fractions are operationally defined as: (i) water-soluble, (ii) clay- and carbonate-bound and exchangeable, (iii) organic, (iv) amorphous Fe and Mn oxides, and (v) crystalline Fe oxides (Reith et al., 2005). Given in the table are the means and standard deviations of the triplicate samples and the significant differences between analogous extractions determined by two-tailed $t$ tests at significance level of $p=0.05$.

incubation in concentrations below $40 \mathrm{ng} \mathrm{g}^{-1}$ (d.w. quartzvein material), and reached a maximum of $550 \mathrm{ng} \mathrm{g}^{-1}$ (d.w. quartz-vein material) at day 35 of the incubation and decreased afterwards (Fig. 4B). In the biologically inactive control experiment, i.e., QJ2-i, no Au was detected in the solution, except for two samples from one of the duplicates at days 14 and 50 days which with $50 \mathrm{ngg}^{-1}$ (d.w. quartz-vein material), and thus lay in the range of the water-soluble $\mathrm{Au}$ extracted from the quartz host rock during sequential leaching (Reith et al., 2005). The starting $\mathrm{pH}$ in biologically active microcosms was 5.2 and in sterilized microcosms approximately 5 (Fig. 4C). Generally, the $\mathrm{pH}$ increased in the biologically active microcosms to $\approx 6.0$ and remained constant after day 25. In sterile microcosms the $\mathrm{pH}$ stabilized at $\approx 5.0$.

\subsubsection{Microbial mechanisms of Au solubilization}

Gold concentrations in the experimental solutions were significantly higher in biologically active microcosms compared to the biologically inactive controls, where in most experiments $\mathrm{Au}$ was below detection. This indicates that resident microbiota play a major role in the solubilization of Au. Different physiological mechanisms of Au solubilization involving a variety of groups of bacteria have been investigated under in vitro conditions. The solubilization of $\mathrm{Au}$ in the QJ2-a might have been mediated by bacterial 
oxidation of the pyrite and arsenopyrite, which include the $\mathrm{Au}$ at the Tomakin Park Gold Mine. Iron- and sulfur-oxidizing bacteria have been shown to liberate Au from sulfide minerals such as pyrite and arsenopyrite (e.g., Ubaldini et al., 2000; Rawlings, 2002). The organisms use ferrous iron and sulfide as electron donors in their metabolisms and oxidize them to ferric iron, thiosulfate, and sulfate, respectively (e.g., Brock et al., 1996). In this process, the mineral is dissolved and the $\mathrm{Au}$, which is often bound in lattices or incorporated into the crystal structure of these minerals, is liberated (King, 2002; Rawlings, 2002).

The solubilization of $\mathrm{Au}$ in the top soils is more likely to be linked to the activity of the heterotrophic bacteria, which have been shown to dominate bacterial communities in oxic soils with high organic matter contents, i.e., 9.6 wt. $\%$ and 0.7 wt. $\%$ in the Ah- and B-horizon at the Tomakin Park Gold Mine (e.g., Paul and Clark, 1996). Heterotrophic bacteria excrete organic substances such as proteins and peptides, amino acids, carboxylic acids and nucleic acids (Korobushkina et al., 1983; Sand, 1997), some of which have been shown to be able to form stable complexes with Au (Vlassopoulos et al., 1990). Korobushkina et al. (1983) have shown that several $\mathrm{mg} \mathrm{L}^{-1}$ (growth medium) Au can be solubilized in in vitro studies with heterotrophic bacteria in media containing metallic $\mathrm{Au}$, and using electrophoretic methods they separated Au organic complexes and found that $\mathrm{Au}$ amino acid complexes dominated. To assess if the solubilization of $\mathrm{Au}$ in our experiments was linked to the changes in amino acid concentration in solution, the concentrations of free amino acids in AJ3-a at days 0, 20, and 50 was measured. Since there was no live biomass in the biologically inactive controls, as reported earlier, the production of amino acids would not occur, thus, the concentration of amino acids in the soil solution was only measured in biologically active Ah-horizon microcosms. The total concentration of amino acids was $8.5 \mu \mathrm{M}$ at day 0 , increased to $64.2 \mu \mathrm{M}$ at day 20 and then decreased to $8.0 \mu \mathrm{M}$ at day 50 (Table 3). This indicates an increase in amino acid production and excretion was followed by a increase in amino acid consumption in the microcosms during the incubation. Thirteen different amino acid were detected in solution at day 20 compared to 5 and 4 at days 0 and 50, respectively (Table 3 ). In particular, aspartic acid was detected at days 0 and 20 and threonine was detected at day 20 (Table 3); both these amino acids have been shown to dissolve $\mathrm{Au}$ (Korobushkina et al., 1983).

\subsection{Association of Au with solid soil fractions in the Ah-horizon}

In all microcosm experiments, the concentrations of $\mathrm{Au}$ in solution decreased after 40-60 days of incubation, and Au was apparently precipitated and/or adsorbed to the surfaces of solids such as minerals, organic matter or biota. This was investigated using sequential leaching of solid slurry samples collected at days $0,10,20,30,40$, and 68 of incubator from AJ3-a. The results presented in Fig. 5 indicate that a continuous mobilization and re-precipitation of $\mathrm{Au}$ was occurring during the incubation of the microcosms and highlight the function of the organic matter as reductant and/or sorbent for Au in soils.

In biologically inactive Ah-horizon microcosms generally no $\mathrm{Au}$ was detected in solution, so it was assumed that since there was no active biomass no change in Au adsorption patterns would occur. The total $\mathrm{Au}$ concentration in the initial soil samples from the Ah-horizon over mineralization measured in aqua regia digests was $\approx 700 \mathrm{ng} \mathrm{g}^{-1}$ (d.w. soil) and lay within the $150-1200 \mathrm{ngg}^{-1}$ (d.w. soil) range reported by Reith et al. (2005). The total concentration of $\mathrm{Au}$ added up from the five extractions was $509 \pm 87 \mathrm{ng} \mathrm{g}^{-1}$ (d.w. soil; Fig. 5) compared to $\approx 700 \mathrm{ngg}^{-1}$ (d.w. soil) in aqua regia digests indicating the presence of $\mathrm{Au}$ in the residual phase. The concentration of $\mathrm{Au}$ in the water-soluble fraction was approximately constant during the experiment, but $\mathrm{Au}$ concentrations in the remaining fractions changed significantly during the course of the experiment indicating a microbially mediated micro scale mobilization and re-precipitation of Au (Fig. 5). Apparently, Au was liberated from the operationally defined Mnand $\mathrm{Fe}$-oxides during the first 20 days of incubation and re-adsorbed to the clay-bound and exchangeable fraction. The apparent solubilization of $\mathrm{Au}$ from the $\mathrm{Mn}$ - and $\mathrm{Fe}-$ oxides continued until day 20 , where more Au apparently re-adsorbed to the operationally defined organic matter. After day $20 \mathrm{Au}$ appeared mostly associated with the organic matter indicating the important role of the organic matter for $\mathrm{Au}$ precipitation in the environment. These results are consistent with field studies that have found a marked $\mathrm{Au}$ enrichment in the organic horizons of soil (e.g., Sokoloff, 1950; Boyle, 1979), and where organic matter has been shown to readily bind to $\mathrm{Au}$ (e.g., Ong and Swanson, 1969; Gray, 1998).

The results from another microcosm, i.e., AJ3$\mathrm{a}+\mathrm{AuCl}_{4}^{-}$, where $100 \mu \mathrm{gg}^{-1}$ (d.w. soil) of $\mathrm{Au}$ as $\mathrm{AuCl}_{4}{ }^{-}$ was added to an Ah-horizon microcosm, confirmed the importance of organic matter as a reductant and/or sorbent for Au in soils (Fig. 6). Solid samples were taken after 10 days that were subjected to the five step leaching protocol yielded a total concentration of $\mathrm{Au}$ in the five phases of $99.38 \pm 8.0 \mu \mathrm{gg}^{-1}$ (d.w soil), and most of the $\mathrm{Au}$, i.e., $91 \mathrm{\mu gg}^{-1}$ (d.w soil), was associated with the operationally defined organic matter.

\subsection{Characterization of biofilms on incubated Au pellets}

Gold pellets that had been incubated for 70 days in biologically active microcosms (AJ2-a $+\mathrm{Au}, \mathrm{AJ} 3-\mathrm{a}+\mathrm{Au})$ were partly covered with a macroscopically visible gray patches. Scanning electron micrographs revealed the presence of cellular structures resembling microbial biofilms (Figs. 7A and 8A). The cellular structures, cocci of approximately $1 \mu \mathrm{m}$ in diameter, were uniform in size and morphology (Figs. 8A and B). Approximately one cell per 


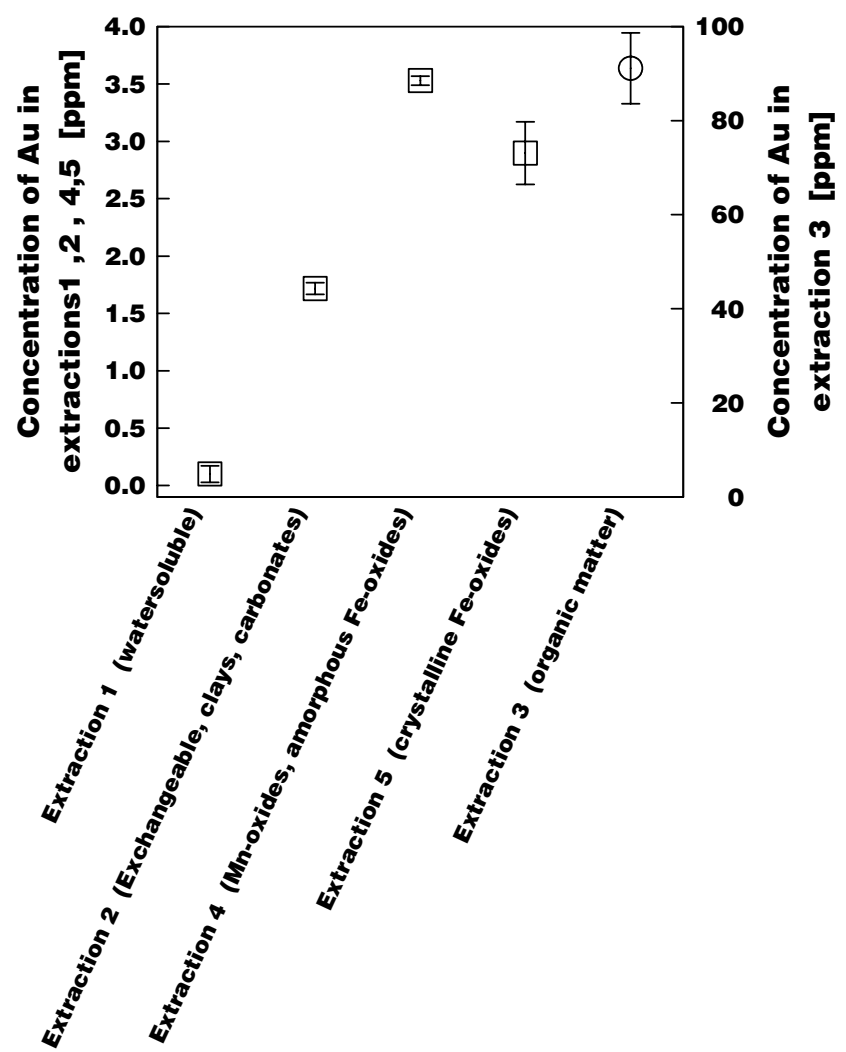

Fig. 6. Distribution of Au in operationally defined soil phases extracted by sequential leaching collected 10 days after amendment with $100 \mu \mathrm{gg}^{-1}$ (d.w. soil) of $\mathrm{Au}$ as $\mathrm{AuCl}_{4}{ }^{-}$. $\mathrm{AJ} 3-\mathrm{a}+\mathrm{AuCl}_{4}{ }^{-}$was conducted in triplicate and error bars depict the standard deviations of the three replicates.

$\mu \mathrm{m}^{2}$ was visible in the scanning electron micrographs. A cracked layer of extracellular polymeric substance (EPS) was apparent between the cells (Figs. 7A, and 8A). EPS layers have been shown to assist in the formation of microcolonies and microbial films on mineral and metal surfaces (Allison and Sutherland, 1987) and are formed by microorganisms immediately after their initial attachment to a surface (Little et al., 1997). The cracking of the EPS layer in our samples probably derived from the air drying and the high vacuum in used the scanning electron microscope.

Backscattered electron imagery (BSE) shows that these cellular structures consist of light elements, because they appeared dark in the secondary image suggesting that they are made up of carbonaceous materials (Fig. 7B). SEMEDXA confirmed the presence of $\mathrm{O}, \mathrm{C}$, and possibly $\mathrm{N}$, indicating that the observed structures consist of organic molecules (Fig. 7C).

$\mathrm{Au}$ pellets were stained using the unspecific nucleic acid stain DAPI. Areas with structures similar to those described above stained positive with DAPI, demonstrating the presence of nucleic acids in the apparent biofilms on Au pellets (Figs. 8C and D). High resolution imagery revealed an uneven distribution of the stain in the biofilm indicating the successful staining of nucleic acids in individual cells (Fig. 8D). Areas where no cellular structures were observed did not stain positive with DAPI, nor did Au pellets not incubated in the soil.

In microcosm AJ2-a $+\mathrm{Au}$ a maximum of $2930 \mathrm{ngg}^{-1}$ (d.w. soil) $\mathrm{Au}$ was mobilized compared to $1134 \mathrm{ngg}^{-1}$ (d.w. soil) in the unamended microcosms conducted with the same samples. The total Au content of these samples $\approx 800-1500 \mathrm{ng} \mathrm{g}^{-1}$ (d.w. soil), indicating that approximately half of the Au of the $2930 \mathrm{ngg}^{-1}$ (d.w. soil) was released from the Au pellets, possibly by the bacteria that form the biofilms. Biofilms have been shown to develop on a wide range of minerals such as iron oxides, carbonates, silicates, and sulfide minerals (Little et al., 1997). They also develop on materials such as steel and other metals, promoting the degradation of the metal surfaces (Beech, 2004). Interfacial processes in the EPS layers appear to play an important
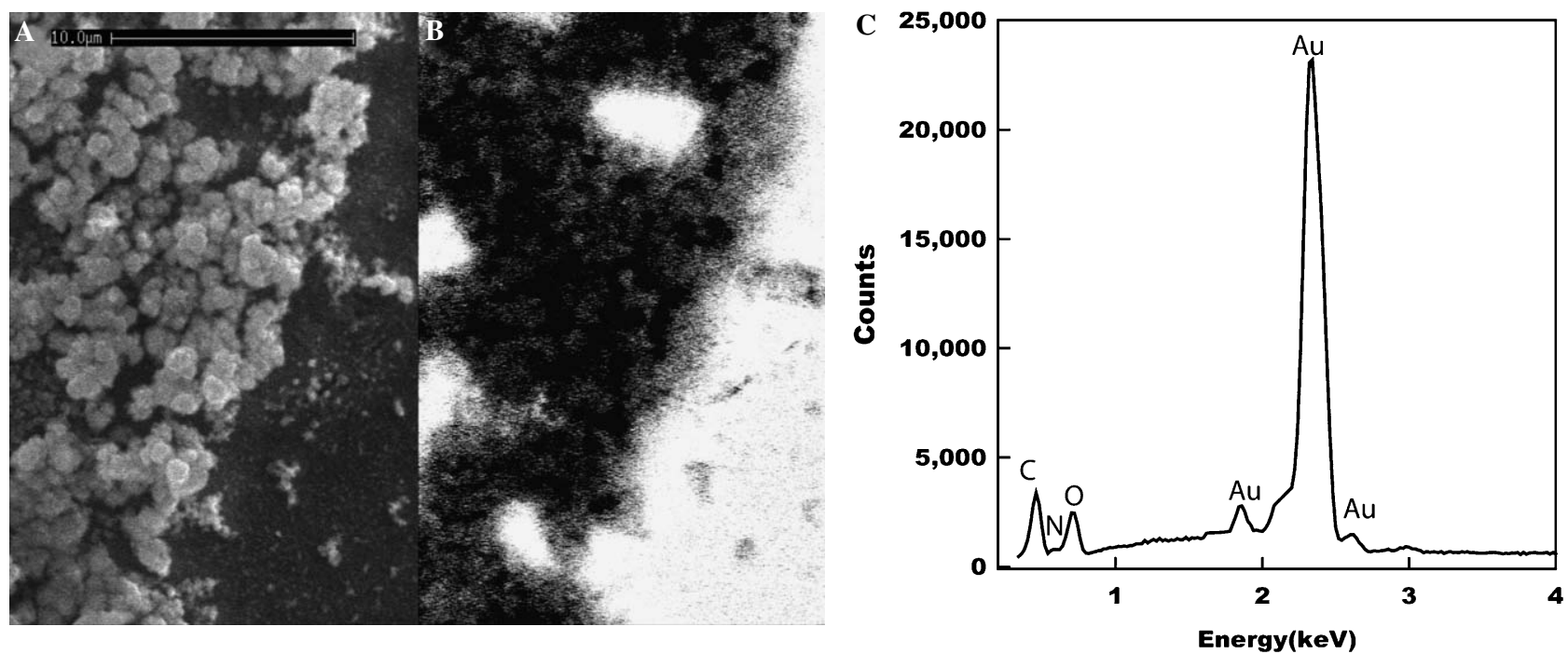

Fig. 7. SEM micrographs and EDX-analysis of a biofilm on a Au pellet incubated for 70 days in biologically active microcosm. (A) Secondary electron image (scale bar $=10 \mu \mathrm{m})$. (B) Backscatter electron image. (C) EDX-analysis of the area. 

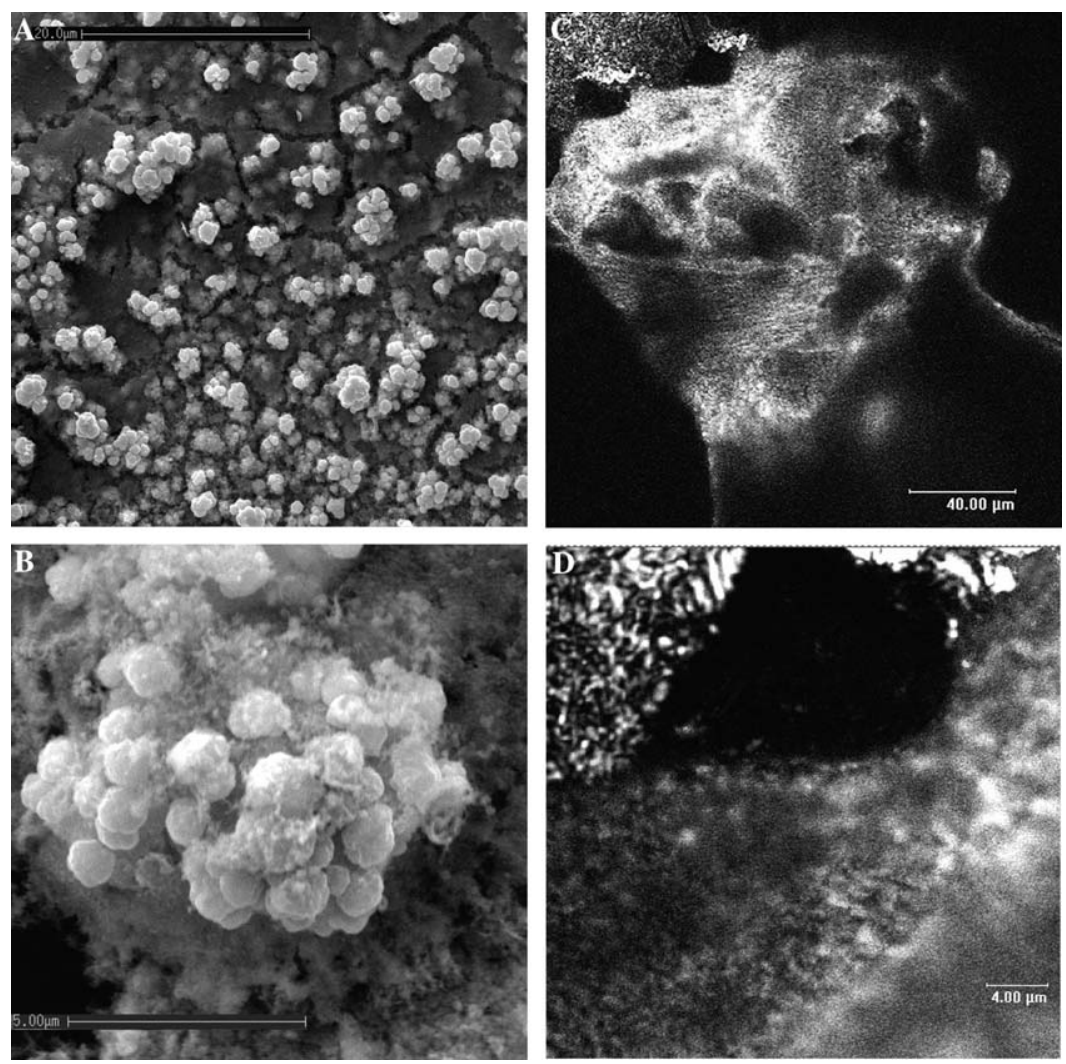

Fig. 8. SEM micrographs and confocal images of a biofilm growing on a Au pellet incubated for 70 days in biologically active microcosms AJ2-a + Au. (A) Secondary electron image showing bacterial cells and the cracked EPS layer (scale bar $=20 \mu \mathrm{m}$ ). (B) Secondary electron image showing a colony of cocci on the Au pellet (scale bar $=5 \mu \mathrm{m}$ ). (C) Confocal image of a biofilm on a Au pellet stained with DAPI (scale bar $=40 \mu \mathrm{m})$. Biofilms appear in light gray, unstained areas appear dark gray or black. (D) A DAPI stained area on a Au pellet biofilm showing cells or cell clusters (light gray), which are separated by unstained interstices (dark gray to black; scale bar $=4 \mu \mathrm{m}$ ).

role in this biocorrosion (Beech, 2004) and have also been shown to play a pivotal role in bioleaching of Au from sulfidic ores such as those containing pyrite (Banfield and Hamers, 2000; Little et al., 1997). Biofilms were not observed on any of the $6 \mathrm{Au}$ pellets incubated in for 70 days in triplicate microcosm A100J2-a $+\mathrm{Au}$, which might explain why $\mathrm{Au}$ was not detected in solution in these microcosms.

\subsection{Community structure analysis}

\subsubsection{Total cell counts and average well color development of the heterotrophic microbial communities in the microcosm} experiments

The results of the cell counts and the average well color development (AWCD) indicate that the microbiota were metabolically active for the length of the incubation in all biologically active microcosms (Fig. 9, Table 4). Total cell counts were conducted with samples from the unamended microcosms AJ2-a, BJ2-a, and QJ2-a. The initial cell counts in $\mathrm{AJ} 2-\mathrm{a}$ and $\mathrm{BJ} 2$-a were $6.74 \times 10^{10}$ and $5.57 \times 10^{10}$ cells g $^{-1}$ (d.w. soil), respectively, as shown in Fig. 9. The number of cells in QJ2-a was one order of magnitude lower. During the first 4 days of incubation the cell number in AJ2-a increased, subsequently decreased to approximately half the initial number by day

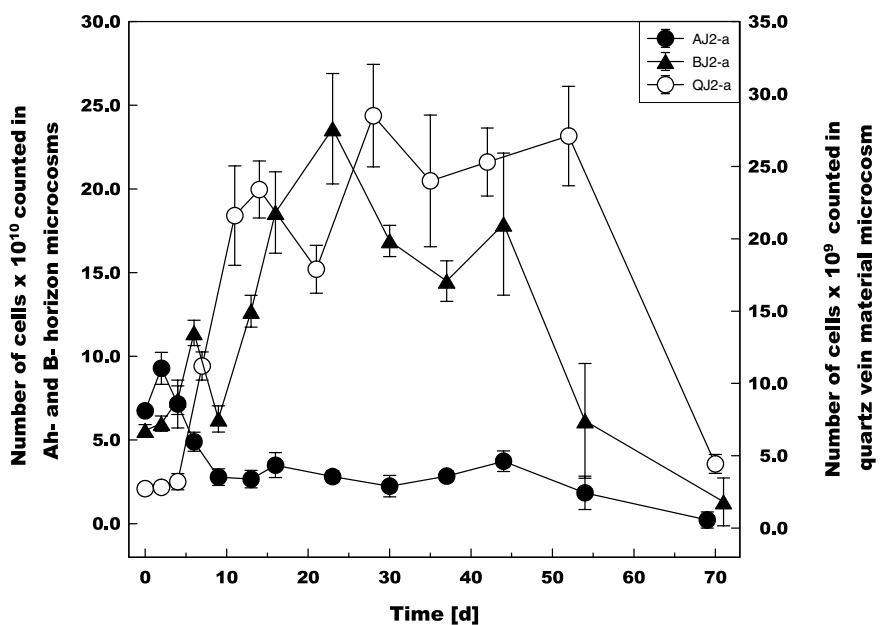

Fig. 9. Total cell counts of bacteria in the biologically active, unamended Ah- and B-horizons and the quartz-vein microcosms. The microcosms were incubated under oxic conditions in a 1:4 aqueous dilution (w:v) on a shaking incubator at $25^{\circ} \mathrm{C}$. Error bars depict the standard errors of the 100 of 400 fields counted on a haemocytometer.

10 , is nearly constant up to day 50 and then decreased

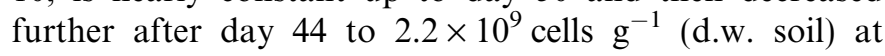
day 68 . In BJ2-a, cell numbers increased $\approx 4$ times the initial number after 23 days of incubation. Cell numbers 
then remained approximately constant at three times the initial cell number and then decreased to less than the initial cell number after 70 days. Cell numbers in QJ2-a increased by a factor of 10 after 23 days, remained approximately constant until day 51 and then decreased to the initial number at day 68 .

In our experiments, the dissolution of $\mathrm{Au}$ did not start immediately after the start of the incubation (Figs. 2-4). The majority of $\mathrm{Au}$ was released after 20-40 days of incubation. This might either indicate a lag-phase at the beginning of the incubation, which is often triggered by the change in the environmental conditions between field and laboratory (Brock et al., 1996). Gold was not detected in the experimental solutions after 50-70 days (Fig. 2-4), suggesting that the bacterial community in the microcosms changed, and that the new bacterial community did not promote the solubilization of Au.

To monitor the development and changes occurring in the heterotrophic aerobic bacterial community, BIO$\mathrm{LOG}^{\mathrm{TM}}$ Ecoplates were inoculated with slurry samples taken $0,10,20,30,40$, and 68 days after the start of the incubation from microcosms $\mathrm{AJ} 3-\mathrm{a}, \mathrm{AJ} 3-\mathrm{a}+\mathrm{Au}, \mathrm{A} 100 \mathrm{~J} 3-$ a, BJ3-a, and B100J3-a (Table 4). Following an initial lag-phase of 24-30 h, the AWCD values increased markedly between 30 and $100 \mathrm{~h}$ after inoculation. For samples taken at day 0 , maximum absorbance values of 1.44 and 1.51 were reached after $120 \mathrm{~h}$ after inoculation in the AJ3-a and $\mathrm{AJ} 3-\mathrm{a}+\mathrm{Au}$, respectively (Table 3). The AWCD of the $\mathrm{BJ} 3-\mathrm{a}$ and $\mathrm{B} 100 \mathrm{~J} 3-\mathrm{a}$ were generally lower compared to day 0 . At day 20 the maximum AWCD was generally less by $\approx 10-20 \%$ in all experiments compared to the day 10 values (Table 4). Samples taken from the AJ3-a and A100J3-a at days 30, 40, and 68 displayed significantly lower AWCD values compared to the initial values, whereas in the $\mathrm{BJ} 3-\mathrm{a}$ and $\mathrm{B} 100 \mathrm{~J} 3-\mathrm{a}$ the maximum AWCD were in the range of the initial values (Table 4). AWCD values of AJ3-a $+\mathrm{Au}$ were between 1.24 and 1.33 for the first 40 days, and at day 68 the absorbance was lower. These results suggest that despite the higher cell number in the B-horizon microcosm, the activity of the organisms and their ability to rapidly use different carbon sources was higher in the Ah- than in the B-horizon.

Table 4

Mean absorbance at $590 \mathrm{~nm}$ after $120 \mathrm{~h}$ of incubation of the Biolog plates for selected microcosms

\begin{tabular}{|c|c|c|c|c|c|}
\hline \multirow{2}{*}{$\begin{array}{l}\text { Time } \\
\text { [d] }\end{array}$} & \multicolumn{5}{|c|}{ Microcosms } \\
\hline & AJ3-a & A100J3-a & BJ3-a & B100J3-a & $\mathrm{AJ} 3-\mathrm{a}+\mathrm{Au}$ \\
\hline \multicolumn{6}{|c|}{$\mathrm{AWCD}^{\mathrm{a}} 590 \mathrm{~nm}$} \\
\hline 0 & 1.44 & 1.51 & 0.84 & 0.94 & n.d. ${ }^{b}$ \\
\hline 10 & 1.50 & 1.28 & 0.74 & 1.05 & 1.27 \\
\hline 20 & 1.33 & 0.97 & 0.62 & 0.84 & 1.24 \\
\hline 30 & 0.94 & 1.06 & 0.76 & 0.77 & 1.32 \\
\hline 40 & 0.90 & 1.34 & 0.89 & 0.77 & 1.33 \\
\hline 68 & 0.67 & 1.28 & 1.04 & 0.88 & 1.11 \\
\hline
\end{tabular}

${ }^{\mathrm{a}}$ AWCD, average well colour development.

b n.d., not detected.

\subsubsection{Changes in the substrate utilization patterns}

Principal component analysis (PCA) performed on the carbon utilization patterns illustrates differences in the development of the bacterial community structures during the incubation of the microcosms that are likely to be linked to the solubilization and precipitation pattern of $\mathrm{Au}$ in the microcosms, as shown in Fig. 10. The first and second principle components, $\mathrm{PC} 1$ and $\mathrm{PC} 2$, accounted for $35.7 \%$ and $31.2 \%$ of the variance of the data. For the first 20 days of incubation the patterns for the AJ3-a, A100J3-a, and BJ3-a display similar component loadings of $0.8-0.9$ on PC1 and $0.3-0.5$ on PC2. The patterns evolving at and after day 30 for the A100J3-a, BJ3-a, and B100J3-a generally show loadings of $0.15-0.35$ on $\mathrm{PC} 1$ and $0.7-0.9$ on PC2. After 30 days of incubation, the AJ3-a and A100J3-a display factor loadings of 0.45-0.55 on PC1 and 0.35 on PC2. These results indicate a general change in the structure of the bacterial community of unamended microcosms between day 20 and 40 .

To investigate which groups of carbon sources on the BIOLOG $^{\mathrm{TM}}$ Ecoplates are reflected in PC1 and PC2, substrates were categorized into six substrate guilds, as previously described by Zak et al. (1994): carbohydrates (6); carboxylic acids (10); polymers (4); amino acids (5); amines (3); and miscellaneous (3), where numbers in parentheses represent the number of substrates in each group. These groups were analyzed by PCA. The results show that the utilization of polymers and carbohydrates were dominantly linked to PC1, whereas utilization of amino acids and carboxylic acids was mostly linked to PC2.

During the first 20-30 days of incubation the Biolog results show that the dominant organisms were those that utilize carbohydrates and amids. These groups of substances are found in soil as humic substances such as humic and

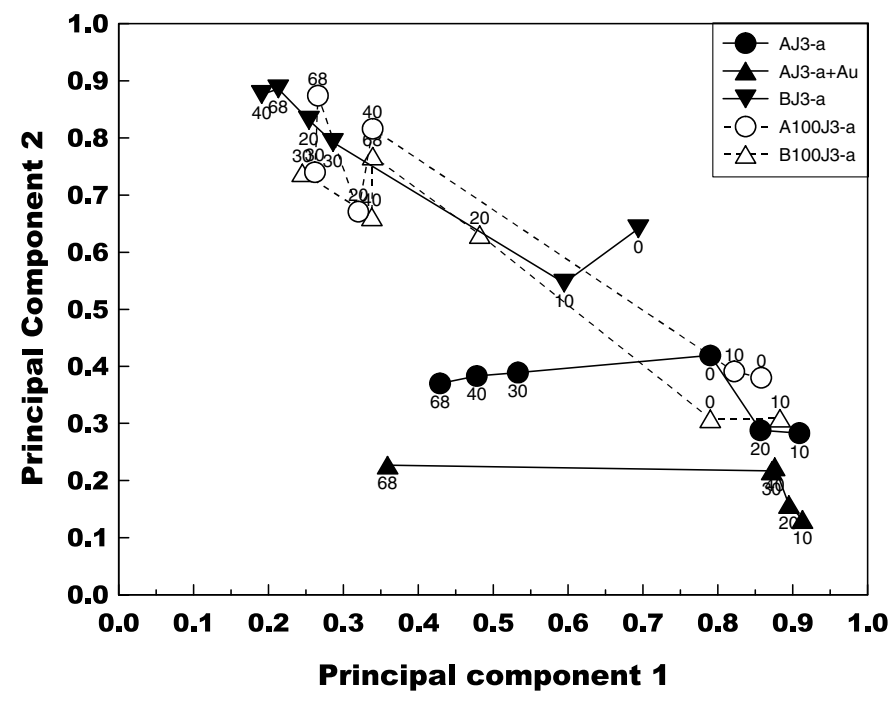

Fig. 10. Results of multivariate principal component analysis (PCA) on substrate class utilization patterns of bacterial communities during the incubation. Numbers next to symbols refer to the number of days for each experiment. 
fulvic acids, and non-humic substances such as polysaccharides, lignins, and chitins, and form a major part of the non-reactive organic soil fraction (e.g., Baldock and Nelson, 2000). The initial bacterial communities of the soil in our experiments is well adapted to utilizing these substances as carbon- and energy sources. During the microbial decomposition of polymers and carbohydrates, organic acids such as amino acids were produced and released into the soil solution (this study; Paul and Clark, 1996). Thus, the rising concentrations of $\mathrm{Au}$ in the solution between day 20 and 45 might to be linked to the presence of $\mathrm{Au}$ complexing amino acids (as discussed in section 4.1.4), which are being produced and excreted more rapidly by the organisms initially dominating the bacterial community than they are consumed.

Gold precipitated or adsorbed to the solid soil fractions after 40-60 days of incubation and the organisms, which dominantly utilize amino acids and carboxylic acids and started to dominate the bacterial community in the microcosms after $\approx 40$ days. This is also associated with much lower concentrations of amino acids at day 50, indicating an increasing consumption or a declining production and excretion of amino acids (Table 3 ). When the amino acids and carboxylic acids are been utilized more rapidly than they are produced, the Au-ions, if present in solution are left without complexing ligands, become unstable in solution, precipitate and/or re-adsorb to the solid soil phases, apparently dominantly to the organic fraction.

\subsection{Implications the behavior of $A u$ and exploration for $A u$ in the regolith}

Understanding the processes influencing the mobilization, transport, and precipitation of Au will lead to an improved understanding of the distribution of $\mathrm{Au}$ in the regolith, which will be vital for the development of successful Au exploration methods and -strategies. Many attempts have been made to link the primary lithology and mineralogy, the local climate, morphology, and topography or the abiotic chemical and physical characteristics of the weathering profile with the processes of $\mathrm{Au}$ mobilization, transport, and precipitation (e.g., Lakin et al., 1974; Mann, 1984; Webster and Mann, 1984; Wilson, 1984). However, no attempt had been made so far to assess the microbial influence on the dissolution of $\mathrm{Au}$ in the regolith in order to answer the question, whether or not we need to account for a microbial mediated $\mathrm{Au}$ dissolution in the environment. The work described in this paper clearly shows that we need to take the activity of Au-mobilizing microorganisms in natural systems into account. The results of previous studies conducted under in vitro condition have shown that Au was solubilized by amino acids, which had been produced and excreted by microorganisms (Korobushkina et al., 1983), the results of this study suggest that this process may be important for the dissolution of Au in natural systems. The amino acids tryptophan and lysine have been shown to from 4 to $8 \mathrm{~nm}$ sized water-dis- persible Au nanoparticles (Selvakannan et al., 2004; Mandal et al., 2005). This indicates that amino acids might not only contribute to the dissolution of Au but also to its dispersion in the regolith.

The apparently rapid turnover of Au in soils, which are often used as sampling materials in geochemical exploration, makes it necessary to integrate microbially Au dissolution data into the interpretation of partial and sequential leaching exploration data. These leaching methods are designed to determine how an element is fractionated between different phases of regolith such as a soil or a calcrete to assess if the detected $\mathrm{Au}$ is residual or transported (e.g., Linter and Butt, 1993; McQueen et al., 1999). Many partial and sequential leaching procedures have been developed and tested in the recent years, and much effort was put into to the optimizing of the leaching conditions. However, this study has shown that within only 68 days of incubation of Ah-horizon samples with biologically active microbiota the patterns of $\mathrm{Au}$ association with host material shifted almost completely. This indicates that the results we obtain from partial- or sequential leaching may often only reflect momentary representations of the distribution of trace elements and may change rapidly over short periods of time. This study has also shown the significance of organic matter as a sorbent for $\mathrm{Au}$ in soil materials and it appears to be interesting to further assess the usage of soil organic matter as sampling medium for geochemical exploration.

\section{Conclusions}

The work presented in this paper represents the first successful trial of linking the ability of microorganisms to solubilize $\mathrm{Au}$ with actual $\mathrm{Au}$ mobility data derived from natural regolith samples. By using biologically active versus inactive microcosms an overall effect of the microbiota resident in auriferous soils on Au solubilization has been demonstrated. The results are a good indication of how microbial activity affects Au mobility in soils and regolith more generally, because contrary to studies conducted in microbial growth media with single strains of organisms, natural soil samples have been used. The microbiota resident in these auriferous soil are capable of dissolving finely disseminated $\mathrm{Au}$ bound within the soil fractions, up to $80 \mathrm{wt} \%$ of the $\mathrm{Au}$ in the soil. The microbiota of auriferous soils are also capable of dissolving Au from added Au pellets, given the concentrations were higher than in the soil sample itself and the presence of biofilms on the surfaces of the $\mathrm{Au}$ pellets. In contrast, the microbiota from soil $100 \mathrm{~m}$ from the mineralization, which displays only background $\mathrm{Au}$ values, did not mobilize Au nor form biofilms on added Au pellets indicating that the microbiota are different or act differently in auriferous soils. The changing adsorption patterns of $\mathrm{Au}$ within the solid soil fractions detected during the microcosm experiments indicate that $\mathrm{Au}$ is constantly mobilized and re-adsorbed. The solubilized $\mathrm{Au}$ shows high affinity for carbonates and clays as 
transitional sorbants, but ultimately appears to be sorbed almost exclusively to the organic matter, this changes appears to take place through an intermediate stage where $\mathrm{Au}$ is in solution. These results show clearly that in terms of geochemical exploration the microbially mediated processes of Au solubilizations need to be taken into account, especially when interpreting selective or partial leaching data from near surface samples such as calcrete and soil.

Carbon utilization patterns to study the changes in the structure of the bacterial community combined with the analysis of amino acids in soil solution indicates that the process of excretion of amino acids was important in $\mathrm{Au}$ dissolution in organic rich natural environments, which is consistent with the results of several in vitro studies. In carbon limited system such as the quartz Au vein the resident microbiota also released $\mathrm{Au}$, however, it appears likely that the Au release is appears to be linked to a different microbially mediated $\mathrm{Au}$ solubilization process, probably ironor sulfide oxidation.

The results of this study clearly indicate that bacterial Au solubilization needs to be considered in understanding the mobility of Au in natural systems, but more research is necessary to elucidate the specific mechanisms of how the bacteria interact with the Au. Future microcosm studies should include measurement of all physical, chemical, and biological variables, subject to the need to minimize any disturbance to the microcosms. The species or groups of bacteria and other microorganisms that are important in affecting Au mobility need to be identified more specifically. In addition, the speciation of Au, e.g., dissolved complexes, colloids, needs to be identified. By making these detailed measurements we will be able to learn more about the mechanisms as well as the kinetics of these processes. Ultimately, we will be able to incorporate appropriate data into numerical geochemical models to predict $\mathrm{Au}$ transport, something useful in developing successful strategies for mineral exploration as well as innovative methods for processing $\mathrm{Au}$ ore.

\section{Acknowledgments}

The authors express sincere appreciation to the Cooperative Research Centre for Landscape Environment and Mineral Exploration (CRC LEME) for funding this project, to Geoffrey Smith and the School for Biochemistry and Molecular Biology for the use of the laboratory facilities, to Charlotte Allen at the Research School of Earth Sciences for the ICP-MS analysis, to Peter and Kinuyo Wyatt at Tomakin Park Gold Mine for the access to the property and help during my field trips, to Steve L. Rogers and Susan Welch for their reviews of preliminary versions of the manuscript and to associate editor Dr. J.R. Haas and the anonymous reviewers for their advice concerning the manuscript.

\section{References}

Allison, D., Sutherland, I.W., 1987. The role of exopolysaccharides in adhesion of freshwater bacteria. J. Gen. Microbiol. 133, 1319-1327.

Baldock, A.J., Nelson, P.N., 2000. Soil organic matter. In: Sumner, M.E. (Ed.), Handbook of Soil Science. CRC Press, Boca Raton, USA, pp. B25-B71.

Banfield, J.F., Hamers, R.J., 2000. Process at minerals surfaces with relevance to microorganisms and prebiotic systems. In: Banfield, J.F., Nealson, K.H. (Eds.), Geomicrobiology: Interactions Between Microbes and Minerals, Reviews in Mineralogy, Vol. 35. Mineralogical Society of America, Washington D.C., USA, pp. 81-117.

Beech, I.B., 2004. Corrosion of technical materials in the presence of biofilms - current understanding and state-of-the-art methods of study. Int. Biodeter. Biodegr. 53 (3), 177-183.

Beveridge, T.J., Murray, R.G.E., 1976. Uptake and retention of metals by cell walls of Bacillus subtilis. J. Bacteriol. 127, 1502-1518.

Bischoff, G.C.O., 1994. Gold-adsorbing bacteria as colonisers on alluvial placer gold. Neues Jahrb. Geol. Paläont. Abh. 194, 187-209.

Bischoff, G.C.O., 1997. The biological origin of bacterioform gold from Australia. Neues Jahrb. Geol. Paläont. Abh. H6, 329-338.

Bischoff, G.C.O., Coenraads, R.R., Lusk, J., 1992. Microbial accumulation of gold: an example from Venezuela. N. Jahrb. Geol. Paläont. Abh. 194, 187-209.

Bosecker, K., 1997. Bioleaching: metal solubilization by microorganisms. FEMS Microbiol. Rev. 20, 591-604.

Bowman, H.N., 1979. A brief inspection of the Tomakin Park Gold Mine, Geol Surv. Rep. Gs 1979/256, Dept. Mineral Resources and Development, Sydney, Australia.

Boyle, R.W., 1979. The geochemistry of gold and its deposits. Geol. Surv. Can. Bull. 280, 579.

Brock, T.D., Madison, M.D., Martinko, J.M., Parker, J., 1996. Biology of Microorganisms, eighth ed. Prentice-Hall, NJ, USA.

Chao, T.T., 1984. Use of partial dissolution techniques in geochemical exploration. J. Geochem. Explor. 20, 101-135.

Garland, J.L., Mills, A.L., 1991. Classification and characterization of heterotrophic microbial communities on the basis of patterns of community-level-carbon-source-utilization. Appl. Environ. Microbiol. 57, 2351-2359.

Garland, J.L., 1996. Analytical approaches to the characterisation of samples of microbial communities using patterns of potential $\mathrm{C}$ source utilization. Soil Biol. Biochem. 28, 223-230.

Gray, D.J., 1998. The aqueous chemistry of gold in the weathering environment. Cooperative Research Centre for Landscape Evolution and Mineral Exploration, Open File Report, 38. Wembley West, Australia, $50 \mathrm{p}$.

Gray, D.J., Lintern, M.J., 1998. Further aspects of the chemistry of gold in some Western Australian soils. Cooperative Research Centre for Landscape Evolution and Mineral Exploration (CRC LEME), Open file report 34, Wembley West Australia, 44 p.

Gray, D.J., Lintern, M.J., Longman, G.D., 1999. Selective and partial extraction analyses of transported overburden for gold exploration in the Yilgarn Craton, Western Australia. J. Geochem. Explor. 67, $51-66$

Greffie, C., Benedetti, M., Parron, C., Amouric, M., 1996. Gold and iron oxide associations under supergene conditions: an experimental approach. Geochim. Cosmochim. Acta 60, 1531-1542.

Grimm, B., Friedrich, G., 1988. Gold in lateritic 1 soils from Central Bahia, Brazil. Geowissenschaftliches Lateinamerika-Kolloquium Tagungsheft. Mineral., Vol. 11, Univ. Hannover Inst.

Guckert, J.B., Carr, G.J., Johnson, T.D., Hamm, B.G., Davidson, D.H., Kumagai, Y., 1996. Community analysis by Biolog: curve integration for statistical analysis of activated sludge microbial habitats. $J$. Microbiol. Methods 27, 183-197.

Hall, G.E.M., MacLaurin, A.I., Garrett, R.G., 1998. Assessment of the $1 \mathrm{M} \mathrm{NH}_{4} \mathrm{NO}_{3}$ extraction protocol to identify mobile forms of $\mathrm{Cd}$ in soils. J. Geochem. Explor. 64 (1-3), 153-159. 
Hall, G.E.M., MacLaurin, A.I., Vaive, J.E., 1995. Readsorption of gold during the selective extraction of the "soluble organic" phase of humus, soil and sediment samples. J. Geochem. Explor. 54, 27-38.

Hirsch, P., Eckhardt, F.E.W., Palmer Jr., R.J., 1995. Methods for the study of rock-inhabiting microorganisms-a mini review. J. Microbiol. Methods 23, 143-167.

Hitzl, W., Henrich, M., Kessel, M., Insam, H., 1997. Application of multivariate analysis of variance and related techniques in soil studies with substrate utilization tests. J. Microbiol. Methods 30, 81-89.

Hosea, M., Greene, B., McPherson, R., Henzl, M., Alexander, M.D., Darnall, D.W., 1986. Accumulation of elemental gold on the alga Chlorella vulgaris. Inorg. Chim. Acta 123, 161-165.

Iglesias, N., Carranza, F., 1995. Bacterial leaching of a copper ore rich in gold and silver: study of the chemical stage. Minerals Eng. 8 (10), 10891096.

Karamushka, V.I., Gruzina, T.G., Podolska, V.I., Ulberg, Z.R., 1987a. Interaction of glycoprotein of Bacillus pumilis cell wall with liposomes. Ukr. Biokhim. Zh. 59, 70-75.

Karamushka, V.I., Ulberg, Z.R., Gruzina, T.G., Podolska, V.I., Pertsov, N.V., 1987b. Study of the role of surface structural components of microorganisms in heterocoagulation with colloidal gold particles. Pricl. Biokhim. Microbiol. 23, 697-702.

Karthikeyan, S., Beveridge, T.J., 2002. Pseudomonas aeruginosa react with and precipitate toxic soluble gold. Environ. Microbiol. 4 (11), 667-675.

Keeling, J.R., 1993. Microbial influence in the growth of alluvial gold from Watts Gully, South Australia. S. Aust. Geol. Surv. Q. Geol. N. 126, 12-19.

King, R.J., 2002. Arsenopyrite. Geol. Today 18 (2), 72-78.

Korobushkina, E.D., Chernyak, A.S., Mineyev, G.G., 1974. Dissolution of gold by microorganisms and products of their metabolism. Mikrobiologiya 43, 9-54.

Korobushkina, E.D., Karavaiko, G.I., Korobushkin, I.M., 1983. Biochemistry of gold. In: Hallberg, R. (Ed.), Environmental Biogeochemistry. Ecol. Bull, Vol. 35. Publishing House of the Swedish Research Councils, Stockholm, pp. 325-333.

Küsel, K., Wagner, C., Drake, H.L., 1999. Enumeration and metabolic product profiles of the anaerobic microflora in the mineral soil and litter of beech forest. FEMS Microbiol. Ecol. 29 (1), 91-105.

Lakin, H.W., Curtin, G.C., Hubert, A.E., Shacklette, H.T., Doxtader, G., 1974. Geochemistry of gold in the weathering cycle. US Geol. Bull. 1330, 80 .

Larsson, A., Akerman, B., Jonsson, M., 1996. DAPI staining of DNA: Effect of change in charge, flexibility, and contour length on orientational dynamics and mobility of the DNA during agarose gel electrophoresis. J. Phys. Chem. 100, 3252-3263.

Levchenko, L.A., Sadkov, A.P., Lariontseva, N.V., Koldasheva, E.M., Silova, A.K., Shilov, A.E., 2002. Gold helps bacteria to oxidize methane. J. Inorg. Biochem. 88, 251-253.

Linter, M., Butt C.R.M., 1993. Pedogenic carbonate; an important sampling medium for gold exploration in semi-arid areas. Exploration Research News/CSIRO Division of Exploration Geoscience 7, 7-11.

Little, B.J., Wagner, P.A., Lewandrowski, Z., 1997. Spatial relationships between bacteria and mineral surfaces. In: Banfield, J.F., Nealson, K.H. (Eds.), Geomicrobiology: Interactions Between Microbes and Minerals, Reviews in Mineralogy, 35. Mineralogical Society of America, Washington DC, USA, pp. 123-155.

Lyalikova, N.N., Mockeicheva, L.Y., 1969. The role of bacteria in gold migration in deposits. Microbiology 38 (5), 682-686.

Mandal, S., Phadtare, S., Sastry, M., 2005. Interfacing biology with nanoparticles. Curr. Appl. Phys. 5, 118-127.

Mann, A.W., 1984. Mobility of gold and silver in lateritic weathering profiles: Some observations from Western Australia. Econ. Geol. 79, 38-49.

Mann, S., 1992. Bacteria and the Midas touch. Nature 357, 358-360.

McDonald, R.C., Isbell, R.F., Speight, J.G., Walker, J., Hopkins, M.S., 1998. Australian Soil and Land Survey Field Handbook, second ed. CSIRO Publishing, Australia.
McQueen, K.G., Hill, S.M., Foster, K.A., 1999. The nature and distribution of regolith carbonate accumulations in south-eastern Australia and their potential as a sampling medium in geochemical exploration. J. Geochem. Explor. 67, 67-82.

Mossman, D.J., Reimer, T., Durstling, H., 1999. Microbial processes in gold migration and deposition: modern analogues to ancient deposits. Geosci. Can. 26 (3), 131-140.

Mueller, A.K., Rasmussen, L.D., Soerensen, S.J., 2001. Adaption of the bacterial community to mercury contamination. FEMS Microbiol. Lett. 204, 49-53.

Mukherjee, P., Senapatei, S., Mandal, D., Ahmad, A., Khan, M.I., Kumar, R., Sastry, M., 2002. Extracellular synthesis of gold nanoparticles by the fungus Fusarium oxysporum. Chem. Biochem. 5, 461-463.

Nakajima, A., 2003. Accumulation of gold by microorganisms. World $J$. Microbiol. Biotechnol. 19, 369-374.

Ong, H.L., Swanson, V.E., 1969. Natural organic acids in the transportation, deposition and concentration of gold. Colo. Sch. Mines $Q .64$ (1), 395-425.

Pares, Y., Martinet, R., 1964. Intervention des bacteréries dans de cycle de l'or. Etude biologigue de phénomène. Bur Rech. Geol. Min. (Fr.) Bull 3, $1-29$.

Paul, E.A., Clark, F.E., 1996. Soil Microbiology and Biochemistry, Second Ed. Academic Press, San Diego, USA.

Preston-Mafham, J., Boddy, L., Randerson, P.F., 2002. Analysis of microbial community functional diversity using sole-carbon-source utilisation profiles-a critique. FEMS Microbiol. Ecol. 42, 1-14.

Ran, Y., Fu, J., Rate, A.W., Gilkes, R.J., 2002. Adsortion of Au(I, III) complexes on Fe, Mn oxides, and humic acid. Chem. Geol. 185, 33-49.

Rawlings, D.E., 2002. Heavy metal mining using microbes. Annu. Rev. Microbiol. 56, 65-91.

Reith, F., McPhail, D.C., Christy, A.G., 2005. Bacillus cereus, gold and associated elements in soil and other regolith samples from Tomakin Park Gold Mine in south-eastern New South Wales, Australia. $J$. Geochem. Explor. 85, 81-98.

Sand, W., 1997. Microbial mechanisms of deterioration of inorganic substrates - a general mechanistic overview. Int. Biodeter. Biodegr. 40 (2-4), 183-190.

Sandstroem, A., Peterson, S., 1997. Bioleaching of a complex sulphide ore with moderate thermophilic and extreme thermophilic microorganisms. Hydrometallurgy 46, 181-190.

Savvaidis, I., Karamushka, V.I., Lee, H., Trevors, J.T., 1998. Microorganism-gold interactions. BioMetals 11, 69-78.

Selvakannan, P.R., Mandal, S., Gole, A., Pasricha, R., Adyanthaya, S.D., Sastry, M., 2004. Water-dispersible tryptophan-protected gold nanoparticles prepared by the spontaneous reduction of aqueous chloroaurate ions by the amino acid. J. Colloid Interface Sci. 269 (1), 97-102.

Shaw, L.J., Beaton, Y., Glover, L.A., Killham, K., Meharg, A.A., 1999. Re-inoculation of autoclaved soil as a non-sterile treatment for xenobiotic sorption and biodegradation studies. Appl. Soil Ecol. 11, 217-226.

Skinner, F.A., 1975. Anaerobic bacteria and their activities in soils. In: Walker, N. (Ed.), Soil Microbiology. Butterworth, London, UK, pp. $1-19$.

Sokoloff, V.P., 1950. Dispersion of gold in rock and soil. Chem. Eng. Min. Rev. 43, 7-10.

Southam, G., Beveridge, T.J., 1996. The occurrence of sulfur and phosphorus within bacterially derived crystalline and pseudocrystalline gold formed in vitro. Geochim. Cosmochim. Acta 60, 4369-4376.

Taylor, J.C., 1991. Computer Programs for Standardless Quantitative Analysis of Minerals Using the Full Powder Diffraction Profile. Powder Diffr. 6, 2-9.

Trevors, J.T., 1996. Sterilization and inhibition of microbial activity in soil. J. Microbiol. Methods 26, 53-59.

Ubaldini, S., Veglio, F.i.F., Toro, L., Abbruzzese, C., 2000. Gold recovery from a refractory pyrrhotite ore by biooxidation. Int. J. Miner. Process 60, 247-262.

Ulberg, Z.R., Karamushka, V.I., Vidybida, A.K., 1992. Interaction of energized bacteria calls with particles of colloidal gold: peculiarities 
and kinetic model of the process. Biochim. Biophys. Acta 1134 (2), 89-95.

vanderLee, G.E.M., deWinder, B., Bouten, W., Tietema, Albert, 1999. Anoxic microsites in Douglas fir litter. Soil Biol. Biochem. 31 (9), 1295 1301.

Vlassopoulos, D., Wood, S.A., Mucci, A., 1990. Gold speciation in natural waters: II. The importance of organic complexing - experiments with some simple model ligands. Geochim. Cosmochim. Acta $\mathbf{5 4}$ (6), 1575-1586.

Webster, J.G., Mann, A.W., 1984. The influence of climate, geomorphology, and primary geology on the supergene migration of gold and silver. J. Geochem. Explor. 22, 21-42.
Wilson, A.F., 1984. Origin of quartz-free gold nuggets and supergene gold found in laterites and soils - a review and some new observations. Aust. J. Earth Sci. 31, 303-316.

Xueqiu, W., 1998. Leaching of mobile forms of metals in overburden: development and application. J. Geochem. Explor. $61(1-3), 39-55$

Yan, F., McBratney, A.B., Copeland, L., 2000. Functional substrate biodiversity of cultivated and uncultivated A horizons of vertisols in NW New South Wales. Geoderma 96, 321-343.

Zak, J.C., Willig, M.R., Moorhead, D.L., Wildman, H.G., 1994. Functional diversity of microbial communities: a quantitative approach. Soil Biol. Biochem. 26, 1101-1108. 